\title{
Supply Side Hysterisis: The Case of the Canadian Unemployment Insurance System*
}

\author{
Thomas Lemieux \\ W. Bentley MacLeod \\ Department of Economics Boston College and C.R.D.E. \\ Université de Montréal
}

October 1994

Revised March 1996

\begin{abstract}
This paper presents results from a 1971 natural experiment carried out by the Canadian government on the unemployment insurance system. At that time they dramatically increased the generosity of the system. We find that the propensity to collect UI increases with a first time exposure to the system. Hence as more individuals experience unemployment, their lifetime use of the system increases. This supply side hysteresis effect may explain why unemployment has steadily increased over the 1972-1992 period, even though the generosity of unemployment insurance did not.
\end{abstract}

*We would like to thank Janet Currie, Chris Ferrall, Christian Gouriéroux, Anne Routhier, and Ging Wong for helpful comments, Ali Bejaoui for research assistance, and FCAR, SSHRC, and HDRC for financial support. 


\section{Introduction}

A recurrent theme in policy debates regarding social welfare programs is the relationship between benefits and the disincentives to work (Moffitt (1992)). In the case of unemployment insurance, there is a great deal of evidence suggesting that it tends to increase both the duration of unemployment and the probability of becoming unemployed. ${ }^{1}$ Moreover work by Katz and Meyer (1990), Corak (1993) and Meyer and Resenbaum (1995) find evidence that workers adjust their labor supply so that unemployment insurance may subsidize part year work. Despite this micro-econometric evidence, there does not seem to be a direct relationship between unemployment insurance benefits and the recent secular rise in the unemployed in the OECD ${ }^{2}$. Lindbeck (1995) has pointed to social norms and the sluggish response of individual labor supply to changes in incentives as a potential source of "supply side hysteresis" that may help explain this secular trend.

In a simple labor supply framework one supposes that changes in worker alternatives results in an immediate behavioral response. However, since the work of Skinner (1953) a great deal of laboratory evidence in psychology has shown that conditioning of individual behavior is the result of experience. In the context of a labor supply model this means that changes in the rewards that the worker is currently experiencing, such as the wage, would have a much greater impact on behavior than changes in the alternative wage. In this paper we find evidence for this effect by showing that for many workers a change in the incentives provided by unemployment insurance had a greater impact on behavior after the worker had some experience with the system.

The study is made possible due to a natural experiment carried out by the Canadian government in 1971. At that time the coverage of the unemployment insurance system was expanded from $68 \%$ to $96 \%$ of the work-force. The number of weeks of work needed to qualify for benefits was reduced from 30 weeks in a two year period to 8 weeks in a single year. The maximum number of weeks during which benefits could be received was increased to 28 or 44 weeks, depending on the regional unemployment rate (in high unemployment regions benefits are more generous). The replacement rate was increased from $57 \%$ of previous earning to $66 \%$ (or $75 \%$ if claimant had dependents). The effect is summarized by the subsidy

\footnotetext{
${ }^{1}$ See for example Topel (1983), Meyer (1990) for the United States, and Ham and Rea (1987) and Green and Riddell (1993) for Canada.

${ }^{2}$ See for example the book by Layard, Nickell and Jackman (1991) and the recent paper by Blanchard and Jimeno (1995).
} 
rate (replacement rate*number of weeks of benefits/number of weeks needed to qualify), and is illustrated in Figure 1 for the period 1946 to 1992.

Given the much shorter benefit period, this creates an incentive to for individuals to tailor their behavior to the parameters of the system, resulting in what many Canadians affectionately call the lotto 10/40. Work 10 weeks and win 42 weeks of paid holidays. The immediate impact of these changes are readily visible in Figure 2, illustrating the evolution of use and cost of the UI system. In 1972 there was a dramatic increase in both the number of recipients of UI and the total cost of the program. However both of these indexes continued to increase over the 1972-1992 period, with the fluctuations in outlay explained by the business cycle (for reference the unemployment rate is also illustrated in Figure 2). The cost of the unemployment insurance system as a fraction of total labor income increased from about $3 \%$ in 1972 to $5 \%$ in 1991 , a $66 \%$ increase. This occurred even though the disincentives for use were either constant or decreased. ${ }^{3}$

To see how conditioning may help explain this observation consider a cohort of workers that were working full-year in 1971, the date of the large scale change to UI. Over time more and more workers from this cohort will have experience unemployment and possibly received some UI. We find that the probability that an individual will receive UI increases when he or she has had experience with the system in the past, implying that the fraction of workers receiving UT should also increase over time, even though the parameters of the system are unchanged. ${ }^{4}$ This also creates a hysteresis effect during recessions. A recession increases the number of workers who leave full-year employment and experience unemployment and UI. The conditioning or learning effect that we identify implies that at the end of the recession the equilibrium number of workers who are unemployed should be greater, and hence the economy does not return to its pre-recession equilibrium level of employment. This may account for the rising trend in the unemployment rate illustrated in Figure 2.

To ensure that we are identifying a behavioral change rather than a structural change in the economy we follow the behavior of individual workers using a large administrative data set. In addition to the usual controls, we are able to control for individual effects, year effects and industry effects. Using a random coefficients probit we find that first time treatment with the unemployment in-

\footnotetext{
${ }^{3}$ The earnings replacement rate of UI was reduced to $60 \%$ in 1978 (from $66 \%$ in 1971 ), $57 \%$ in 1990 , and $55 \%$ in 1993; the minimum qualifying period was extented to 10 weeks in 1978 (from 8 weeks in 1971), and to 12 weeks in 1990.

${ }^{4}$ Heckman and Borjas (1980) call this effect "occurence dependence".
} 
surance system permanently increases future use. In the next section we describe the data. Section 3 presents a discussion of the model, while section 4 provides some preliminary results using a grouped data approach. Section 5 discusses the estimation strategy, while the results are discussed and summarized in sections 6 and 7 .

\section{Data and Descriptive Statistics}

We analyze the dynamics of UI recipiency in Canada using a large longitudinal data set for the years 1972 to 1992. To create this data set, we combine the "Status Vector File" of Employment Immigration Canada (EIC) from 1971 to 1993 with income tax data from the "T4 Supplementary File" of EIC from 1972 to 1991.

These two data sets are complementary. The Status Vector File contains data pertaining to all unemployment insurance claims established by each claimant whose Social Security Number (SIN) ends in the digit '5'. It also contains some demographic information such as the age and sex of the claimant as well as the UI region in which the claim was filed. The drawback of this file is that it has very little information on what happens to claimants before and after their UI claims.

By contrast, the T4 Supplementary File provides no demographic information on workers but it contains records of all sources of T4 income for workers whose SIN ends in the digit ' 5,5 It also provides information on the location and industry of the employer that issued the T4. This file can be used to identify whether a UI claimant received some labor income before and after each UI spell. By combining the two files, it is thus possible to reconstruct a detailed longitudinal history of UI and labor income recipiency from 1972 to 1991 for a large sample of workers.

More precisely, we extract from the Status Vector File all claims that eventually led to the payment of regular UI benefits in the first week of payment. We exclude workers filing claims for special benefits (seasonal, sickness, maternity, etc.) from the analysis. We use the benefit period commencement of each claim to identify the year in which the UI spell started. Once we have identified all the years from 1972 to 1992 in which at least one spell started, we merge this information to the information contained in the T4 Supplementary File. From this file we know when a person first received T4 income. This enables us to identify a "year of entry" in the sampling universe for each UI claimant.

\footnotetext{
${ }^{5}$ The T4 tax form is the Canadian counterpart to the U.S. W2 form.
} 
Table 1 indicates that for close to half of the male UI claimants (slightly less for women), the year of entry is simply the year in which the T4 file starts, that is 1972. For most of these workers, the year of entry is really a year of entry in the sample as opposed to a year of entry in the work-force. For the rest of the sample of claimants, what we call the "year of entry" may either be a true year of entry in the workforce or the year of "re-entry" for people who earned some T4 income before 1972 but no T4 income in 1972. Table 1 nevertheless indicates that the age of entry of half of the claimants (age at which T4 income is first recorded) is 20 or less. This suggests that most of the 50.7 percent of men and 48.6 percent of women whose year of entry is 1973 or later are not re-entrants in the workforce.

Why is it so important to know when a claimant first "entered the workforce"? The answer is that if we want to find out how previous use of the system affects how long it takes before the person receives UI again, we need to know how long it took before the person used UI for the first time. Since different people join the workforce at different times, we need to have some idea of when the person entered the workforce to compute the duration before the first UI spell. Our measure of entry is imperfect since some students earn T4 income during summer jobs even if they have not made a "permanent" transition to the work force. We nevertheless feel this is the best we can do with the available data. We will discuss these issues again in Section IV.

We also use information from the T4 Supplementary File to compute a coarse measure of eligibility to UI. The point is that someone who has not worked at any time during year $t$ and year t- 1 can never qualify for a new UI benefit period starting during year t. This UI eligibility variable can thus be used to correct for potential estimation biases likely to arise when people exit the workforce temporarily or permanently because of early retirement, illness, etc.

Once the year of entry has been identified in the T4 File, this information is merged to the information about demographic characteristics and UI spells from the Status Vector File. The two files are combined into a yearly panel data file. There is one observation per person in the panel for each year (from the year of entry to 1992). For each observation we know whether the individual received some T4 income and whether he or she initiated a UI spell during the year. Note that we do not keep the observation in the sample when the person is under 15 or over 65 years old. We also exclude people born before 1912 or after 1972 . The resulting sample contains $10,253,535$ observations for 618,911 men who have started a UI spell at least once in the years 1972 to 1992. The comparable sample of women contains 8,074,326 observations for 494,697 women. 
A few statistics on the composition of the men's sample are reported in Table 2. The average age in the sample is slightly under 35 . The regional composition of the sample more or less reflects the relative weight of each province in the national population. Note however, that Quebec and especially the Maritimes are overrepresented. This simply reflects the fact that a larger fraction of workforce have received UI at least once in these provinces than in provinces west of Quebec.

The table also shows that men in the sample received at least some T4 income in four years out of five and started a UI spell in one year out of five. These proportions are slightly smaller for women. The probability of receiving a UI claim is disaggregated by provinces and by year in the second column of Table 2. Once again, there are important East-West differences as people in Quebec and the Maritimes are more likely to start a UI spell than people in other provinces. Interestingly, the probability of starting a spell of UI follows the business cycle but shows no obvious upward or downward trend.

\section{The Effect of Unemployment Insurance on Recipiency}

For purposes of exposition it is useful to present a simple formal model that captures many of the incentive effects of UI. Suppose that at time $t$ all workers are completely characterized by their base productivity denoted $\theta_{t}$, and the value of home production denoted by $u_{t}$. The base productivity of a person is a composite variable representing the market value of education, occupation choice and innate skills. Since this variable represents a market value, it will vary over time due to on-the-job training, technical change etc.

In addition to a worker's base productivity, the wage of a worker is also affected by business cycle shocks, including seasonal shocks. Letting $\eta_{t}$ denote the size of this shock in period $t$, suppose that the wage of a worker is given by:

$$
w_{t}=\theta_{t}+\eta_{t} .
$$

Abstracting away for the time required for search, individuals choose employment if and only if the wage is greater than the value of home production or $w_{t} \geq u_{t}$. This is illustrated by the solid line in Figure 3.

To understand how UI may generate unemployment suppose that search costs are negligible so that individuals can find work immediately at some wage. To simplify matters as much as is possible suppose that once an individual has $x$ weeks of insured earnings, she or he is eligible for $y$ weeks of benefits equal to a fraction $\alpha$ of the previous wage. An individual with characteristics $(\theta, u)$ thus 
considers one of the following three options (with the $t$ subscripts dropped for convenience):

1. Work full-year at a wage of $w=\theta+\eta$.

2. Exit the labor force to receive a benefit of $u$.

3. Work the number of periods necessary collect UI and then collect the benefits until exhaustion before beginning to work again ${ }^{6}$. Letting $\delta=x /(x+y)$ be the fraction of time the worker must be employed to earn $y$ weeks of benefits we have that the return to the individual is given by $u i=\delta \cdot w+(1-\delta)(u+$ $\alpha \cdot w)=(\delta+(1-\delta) \alpha) w+(1-\delta) u$. Let us call a worker that follows this strategy a part year worker.

There are four distinct possibilities to consider, illustrated in Figure 3. First there are those workers that prefer full-year work to either part-year work or being out of the labor force. Workers that are indifferent between full-year employment and part-year employment have characteristics satisfying $u=w$, or:

$$
w=(1-\alpha)(\theta+\eta)
$$

This is illustrated by the dotted line in Figure 3.

The line dividing those choosing to be out of the labor force from those who work part year satisfies $u=u i$, or:

$$
u=(1+\alpha(1-\delta) / \delta)(\theta+\eta)
$$

This is illustrated by the dashed line in Figure 3. Observe that UI has both a positive and negative employment effect. Some workers move from full-year employment to part year employment. Others who might ordinarily stay out of the labor force may decide to work part of the year and receive UI benefits for the rest of the year. This is consistentre with the finding of Card and Ridell (1993) that though unemployment gw in Canada during the 1980's, so did labor force participation, particularly by women. Region A consists of jobs created

\footnotetext{
${ }^{6}$ Given the linearity of the system, it is not difficult to show that if agents choose to cycle in and out of UI then they will only work the minimum number of periods needed to qualify. Exactly the same form of behavior is optimal with the more complex system one observes in practice, though with fluctuating labor demand they may work for more periods, to qualify for a greater number of periods of benefits.
} 
by the UI system. A common example would be employment in the arts. A theater company may survive because its members have insured earnings while performing or touring, but collect UI benefits between shows. During this period they may still be rehearsing and preparing for future employment. In the absence of UI many of the performers may not be able to continue their profession. The implications of parameter changes are summarized in the following proposition.

Proposition 3.1. Decreasing the entry requirement, $\delta$, or increasing the replacement rate, $\alpha$, has the following effects:

\section{Participation in the labor force increases.}

2. Number of individuals receiving unemployment insurance per year increases.

\subsection{Hysteresis}

When the major change to the unemployment insurance system occurred in 1971 this increased the incentives for individuals to subsidize part-year employment with UI. Figure 2 shows that the rate of use of UI increased sharply between 1971 and 1972. It then followed an upward trend between 1972 and 1992 even though the underlying incentives (subsidy rate) were constant or declining. In this paper we present evidence that individuals permanently changed their behavior after a bout of experience receiving UI. This evidence points to a potentially important hysteresis effect that should be considered in the design of any social welfare program.

Beginning with Skinner (1953) (see Wickens (1992) for a recent literature review), a great deal of laboratory evidence in psychology has shown that individuals alter their behavior not only in response to potential rewards, but also as a result of receiving these rewards ${ }^{7}$. As individuals learn about the consequences of the UI system through practical experience this can have the effect of permanently changing future behavior. This is most relevant for individuals who are in fullyear employment and then find themselves in region $\mathrm{B}$ after the change to the UI system. The learning model suggests that they would not initially modify their

\footnotetext{
${ }^{7}$ An executive compensation consultant with a leading consulting firm related to the second author that executives begin to alter their behavior after they have begun to experience the relationship between their performance and pay. The existence and commitment to a perfor mance pay system is not sufficient to achieve its full impact on executive behavior. This learning effect is likely to be even stronger with a government program whose intent is not to alter worker behavior.
} 
behavior. However should they find themselves unexpectedly unemployed and receive unemployment insurance benefits, then they are more likely to become aware of the potential to use UI to subsidize part year work.

The simple model can be used to represent the impact of learning on the probability of receiving UI. Suppose that a worker does not understand or take into account the benefits from cycling on and off UI, but simply compares employment with home production. In that case the probability that individual $i$ is out of the labor force in period $t$ is:

$$
P\left(Z_{i t}\right)=\int_{\underline{\theta}}^{\bar{\theta}} \int_{\theta+\eta_{t}}^{\bar{u}} f\left(\theta, u \mid Z_{i t}\right) d u d \theta,
$$

where $f\left(\theta, u \mid Z_{i t}\right)$ is the distribution of individual characteristics as a function of observables $Z_{i t}$ (and assuming that we have a measure of the business cycle shock $\left.\eta_{t}\right)$. The support of the distribution is bounded below $\underline{\theta}$ and $\underline{u}$, and bounded above by $\bar{\theta}$ and $\bar{u}$. Now consider the case when the UI benefits are incorporated into the decision:

$$
P \omega\left(Z_{i t}\right)=\int_{\underline{\theta}}^{\bar{\theta}} \int_{(1+\alpha(1-\delta) / \delta)\left(\theta+\eta_{t}\right)}^{\bar{u}} f\left(\theta, u \mid Z_{i t}\right) d u d \theta
$$

where $\omega=\{\alpha, \delta\}$ represents the parameters of the system. From proposition 3.1 it follows that the probability of receiving UI when one is aware of the system, $P \omega\left(Z_{i t}\right)$ is increasing in the replacement rate, $\alpha$, and decreasing in the entry requirement, $\delta$.

The 1971 reforms had two effects. The first was that the system was expanded to cover more workers. From the point of view of learning, the relevant observation is that $P \omega\left(Z_{i t}\right)$ is larger than $P\left(Z_{i t}\right)$ and that the probability of taking up UI in the absence of experience would be $P\left(Z_{i t}\right)$. Similarly, for those workers that were covered, even if they had previous experience with the system under parameters denoted $\omega^{\prime}$, the 1971 changes imply that $P \omega\left(Z_{i t}\right)>P^{\omega^{\prime}}\left(Z_{i t}\right)$, and hence even for these workers one would expect their probability of receiving UI to increase after they have had some experience.

The next section describes a difference-in-differences approach to see if previous experience has an effect on the probability of use. Section 5 describes a random effects probit model in which the probability of using UI is modelled as a function of a dummy variable indicating if the worker has experienced at least one spell of UI in the past. If the coefficient of this parameter is positive, then this implies that the probability of receiving UI has permanently increased after this experience. 


\section{Longitudinal Analysis}

The descriptive statistics reported in Table 2 do not exploit the longitudinal aspect of the data, nor do they give any indication on how, for example, the past history of UI recipiency is related with the current probability of starting a UI spell. In what follows we present some descriptive statistics that highlight the dynamic aspects of UI recipiency.

One advantage of working with a large data set like ours is that it is easy to control for observed characteristics by dividing the sample in homogeneous groups of people and doing the analysis separately for each group. In what follows we select three cohort of men and three cohorts of women to present some descriptive evidence focusing on the longitudinal aspect of the data. The six cohorts consist of men born in 1931, 1941, and 1951 respectively. The three particular birth years are selected so that people are old enough to be in the workforce in 1972 and young enough to still be in the workforce in 1992.

\subsection{Grouped data evidence on learning effects}

If learning effects are important, a given experience with the UI system should have a larger impact on the future probability of receiving UI for people who had no previous experience with the UI system than for people who had some previous experience. One simple measure of the magnitude of learning effects is thus obtained by comparing the evolution in the probability of UI recipiency of one group of workers that have no previous UI experience with an otherwise comparable group of workers who have had some previous experience.

More concretely, consider a fixed cohort of workers at the beginning of the 1981-83 recession. Some of these workers have received UI in the past while some others have not. Focusing on the 1981-83 period is an interesting "natural experiment" since it "exposed" many workers to unemployment and UI recipiency for the first time in their careers. If learning is important, the post-recession probability (e.g. 1984-86) of these workers to receive UI should be higher than the probability that would have prevailed if they had never been exposed to UI. Although this hypothetical probability cannot be directly observed, a control group of workers that were exposed to UI before the recession can be used to calculate the change in the probability of receiving UI between the recession (1981-83) and the post-recession period (1984-86) that would prevail in the absence of learning effects. The point is that since these workers have already been exposed to the system, a new exposure during the recession should not have any additional effect 
on the future probability of receiving UI. The change in probability for workers that have been exposed before is thus net of learning effects.

This suggests a simple "difference-in-differences" estimator of the effect of learning on the probability of using UI. Table 3 reports separate difference-indifferences estimates of the effect of learning for the cohorts of men and women born in 1931, 1941, and 1951. The estimated effect is positive for all six cohorts, suggesting that a first exposure to UI permanently increases the probability of receiving UI again in the future. These results suggest that part of the upward trend in the use of UI is due to the fact that exposure to the system permanently increases the probability of future use.

\section{Estimation by Random Effect Probit}

In order to look more formally at the dynamics of UI recipiency, consider the following model for the probability that individual $i$ starts a spell of UI in period $t$ :

$$
\operatorname{Pr}\left(U_{i t}=1 \mid U_{i t-1}, x_{i t}, L_{i t}\right)=F\left(\alpha_{i}+\delta_{t}+\gamma U_{i t-1}+x_{i t}^{\prime} \beta+\theta_{0} L_{i t}+\left(x_{i t}^{\prime} \theta_{1}\right) L_{i t}\right),
$$

where $i=1, . ., N, t=1, . ., T, \mathrm{~F}($.$) is a cumulative distribution function. In this$ paper, we simply assume that $\mathrm{F}($.$) is a unit normal. The cumulative distribution$ function $\mathrm{F}($.$) is increasing in its arguments. An increase in arguments such as \alpha_{i}$ or $x_{i t}^{\prime} \beta$ will thus increase the probability that individual $i$ starts a spell of UI in period $t$. The arguments in the function $\mathrm{F}($.$) are listed below:$

- $U_{i t}$ : dummy variable equal to one if individual $i$ starts a UI spell during year $t$,

- $\alpha_{i}$ : time invariant random effect,

- $\delta_{t}$ : aggregate time effect,

- $x_{i t}$ : vector of covariates including the age of person $i$, the parameters of the UI system in individual $i$ 's region at time $t$ and industry dummies.

- $L_{i t}$ : a variable indicating whether or not individual $i$ has "learned" how to use the UI system at time $t$. In the simplest version of the learning model, this variable is one if the individual has received unemployment insurance in the past, and zero otherwise. 
In what follows, we refer to $L_{i t}$ as a learning variable although, more generally, it can simply be viewed as a variable indicating whether the person has ever collected UI in the past. The parameter $\theta_{0}$ relates the learning variable to the probability of receiving UI, while the vector of parameters $\theta_{1}$ indicates whether variables in the vector $x_{i t}$ (such as the replacement rate of UI) have a different impact on UI recipiency for people who have learned than for people who have not learned. In other words, $\theta_{1}$ captures possible interactions between learning effects and variables such as the parameters of the UI system.

To understand why learning effects can be interpreted as "hysteresis" effects in the use of UI, consider the simple case in which $\theta_{1}$ is equal to zero. From the definition of the learning variable $L_{i t}$, it is clear that receiving UI for the first time switches the learning variable $L_{i t}$ from 0 to 1 and thus permanently increases the probability of receiving UI, provided that $\theta_{0}$ is positive. This basic property of learning effects remains when $\theta_{1}$ is different from zero except that the size of the "hysteresis" effect then depends on the value of variables such as replacement and subsidy rates of the UI system.

One difficulty in isolating the importance of learning effects is that many other factors may explain why the history of UI recipiency of a given person i, $\left(U_{i 1}, \ldots, U_{i t-1}\right)$, may help predict whether the person will receive UI in period $t$. To see this, note that except for the learning term $\theta_{0} L_{i t}+\left(x_{i t}^{\prime} \theta_{1}\right) L_{i t}$, equation (5.1) is a standard statistical model for a binary variable with panel data (see?, Heckman (1978), and Heckman (1981a)). In such models, there are two reasons why the history of UI recipiency of a given person i, $\left(U_{i 1}, \ldots, U_{i t-1}\right)$, may help predict whether the person will receive UI in period t. First, certain individuals may be more likely to be unemployed and to receive UI because they are less-skilled and/or they have a high marginal valuation of leisure. These factors are summarized by the random person effect $\alpha_{i}$. Since this random effect is by definition fixed for a given person i over time, it increases the probability that the person will receive UI in any time period. As a result, previous use of UI will be strongly correlated with present use of UI since some people are always likely to receive UI (high $\alpha_{i}$ ), while some people are not (low $\alpha_{i}$ ). This could give the misleading impression that previous use of UI is a cause of the present use of UI. This is called the problem of unobserved heterogeneity.

The history of UI recipiency of a given person $i$ may also help predict whether the person will receive UI in period $t$ because of the presence of the lagged dependent variable $U_{i t-1}$ in equation (5.1). Note that in the estimation we consider models that include further lags of $U_{i t-1}$. We call this particular form of state 
dependence an adjustment lag. It is natural to expect an adjustment lag in the data for a variety of reasons. For instance, it is well known that the rate of job separation is higher in the first year on a job than in subsequent years (see ?). In other words, a job separation is more likely to occur at time $t$ if there was also a separation at time $t-1$ than otherwise. Since UI recipiency is positively correlated with job separations, a UI spell is more likely to be observed in year $t$ if $U_{i t-1}=1$ than if $U_{i t-1}=0$. Alternatively, workers who have lost some specific human capital because of permanent job displacement may be more likely to be unemployed than if they still had that specific human capital. A UI spell due to permanent job displacement may thus increase the future probability of receiving UI. They key difference between an adjustment lag and learning is that the adjustment lag only temporarily affect the probability of receiving UI, while learning effects are permanent.

It should thus be clear that the mere fact that the history of UI recipiency $\left(U_{i 1}, \ldots, U_{i t-1}\right)$ may help predict whether the person will receive UI in period $\mathrm{t}$ is not a proof of the existence of learning effects. The econometric challenge consists in isolating learning effects from the presence of unobserved heterogeneity and adjustment lags. We discuss the econometric strategy in detail below.

The increase in use of UI may be due to structural change both over time and by industry. One explanation for the changes may be due to a shift from industries employing workers full-year, to industries that encourage part-year work. To deal with this potential explanation we include a full set of time and industry controls. Thus if a worker is unemployed for the first time, and then moves into an industry that has a great deal of part-year workers, then even though the use of UI goes up, the estimated learning parameter in this case would be zero.

It is not possible to rule out learning on the part of the firm and worker together. Since UI is not experience rated in Canada, it is possible that firms have an incentive to learn along with the worker the best way to use the UI system to subsidize part-year work. However if this effect is occurring across all firms over time, then the time controls would tend to eliminate any measured learning effects. Given this set of controls, any positive learning effect is evidence that experiencing a spell of receiving UI has the effect of increasing future use. Given that we do not observe all the factors that affect a worker's decision, our results can be expected to underestimate the importance of learning and slow behavioral change.

One final remark is that the variable $L_{i t}$ is only a crude measure of learning. People may also learn how to use the system through friends and family. This 
yields the interesting prediction that the relative role of past UI experience in learning how to use the system should be less important in regions and/or industries in which the use of UI is widespread. One testable implication of this learning model is thus that the coefficient should be lower in high UI regions such as the Maritimes or Quebec than in low UI regions such as Ontario or Alberta.

\subsection{Estimation methods}

Under the assumption that $\mathrm{F}($.$) is a unit normal, the probability that individual$ $i$ will start a spell of UI in period $t$ can be rewritten as:

$$
\operatorname{Prob}\left(U_{i t}=1 \mid U_{i t-1}, L_{i t}, x_{i t}, \alpha_{i}\right)=\Phi\left(\alpha_{i}+\delta_{t}+z_{i t}^{\prime} \omega\right)
$$

where:

$$
z_{i t}^{\prime} \omega=\gamma U_{i t-1}+x_{i t}^{\prime} \beta+\theta_{0} L_{i t}+\left(x_{i t}^{\prime} \theta_{1}\right) L_{i t}
$$

The probability of observing a sequence $\left(U_{i 1}, \ldots, U_{i T}\right)$ of UI spells is thus equal to:

$$
\prod_{t=1}^{T} \Phi\left(\alpha_{i}+\delta_{t}+z_{i t}^{\prime} \omega\right)^{\left(1-U_{i t}\right)}\left(1-\Phi\left(\alpha_{i}+\delta_{t}+z_{i t}^{\prime} \omega\right)^{U_{i t}}\right.
$$

This probability is the essential building block of the likelihood function to be maximized. There are two important issues, however, that need to be addressed before the model can be estimated. First, the probability in equation (5.4) is conditional on a particular value of the random effect $\alpha_{i}$. Since the random effect is not observed, we need to integrate over its distribution to obtain an unconditional probability of observing the sequence $\left(U_{i 1}, \ldots, U_{i T}\right)$ :

$$
\int \prod_{t=1}^{T} \Phi\left(\alpha_{i}+\delta_{t}+z_{i t}^{\prime} \omega\right)^{\left(1-U_{i t}\right)}\left(1-\Phi\left(\alpha_{i}+\delta_{t}+z_{i t}^{\prime} \omega\right)^{U_{i t}} d G\left(\alpha_{i}\right),\right.
$$

where G(.) is the cumulative distribution function of the random effect $\alpha_{i}$.

The log-likelihood function of the model is then obtained by summing up the $\log$ of $(5.5)$ over all the observations:

$$
\sum_{i=1}^{N} \log \left(\int \prod_{t=1}^{T} \Phi\left(\alpha_{i}+\delta_{t}+z_{i t}^{\prime} \omega\right)^{\left(1-U_{i t}\right)}\left(1-\Phi\left(\alpha_{i}+\delta_{t}+z_{i t}^{\prime} \omega\right)^{U_{i t}} d G\left(\alpha_{i}\right)\right)\right.
$$


Since we have already assumed that the cumulative distribution function $\mathrm{F}($. was normal, it seems natural to follow authors like Heckman (1981b) and assume that G(.) is also normal. In general, evaluating the log-likelihood function (5.6) requires some numerical integration, which is computationally burdensome in a large panel data set like the one used here. We thus follow the initial suggestion of Lehman and Manski (1981) of randomly drawing values of $\alpha_{i}$ to evaluate the likelihood function. See also Gourieroux and Monfort (1993) for a recent survey of simulation-based estimation methods.

To see the basic idea of the simulated maximum likelihood (SML) method, first rewrite the random effect $\alpha_{i}$ as $\alpha_{i}=\alpha+\sigma \alpha u_{i}$, where $u_{i}$ is a standard normal random variable and $\sigma \alpha$ is the standard deviation of $\alpha_{i}$. The log-likelihood function (5.6) can then be approximated by randomly drawing $\mathrm{K}$ values $\widetilde{u}_{i}^{1}, \ldots, \widetilde{u}_{i}^{K}$ of $u_{i}$ :

$$
\sum_{i=1}^{N} \log \left[\frac{1}{K} \sum_{j=1}^{K}\left(\prod_{t=1}^{T} \Phi\left(\alpha+\delta_{t}+z_{i t}^{\prime} \omega+\sigma \alpha \tilde{u}^{j}\right)^{\left(1-U_{i t}\right)}\left(1-\Phi\left(\alpha+\delta_{t}+z_{i t}^{\prime} \omega+\sigma \alpha \tilde{u}^{j}\right)^{U_{i t}}\right)\right]\right.
$$

We will refer to the estimates obtained by maximizing equation (5.7) as SML estimates. It is well known (Lehman and Manski (1981), Gourieroux and Monfort (1993)) that SML estimates are only consistent when the number of draws K goes to infinity. We thus use $\mathrm{K}=20$ in the empirical analysis presented below. ${ }^{8}$

The second important estimation issue arise because of the nature of the administrative files that we used to construct the data set used for the estimation. Since the Status Vector only contains information on workers who file a UI claim at least one, we have no demographic information on workers who never filed a claim. We thus have to correct for the potential sample selection biases that could result from the way the final sample is constructed.

One way of handling this selection problem would be to use the parameters of the model to compute the probability that a worker experiences at least one spell of UI during the sample period. A resulting conditional log-likelihood function could then be maximized. It would yield consistent estimates of the parameters. ${ }^{9}$

\footnotetext{
${ }^{8}$ We noticed in several empirical experiments that there were only small differences between the estimates obtained with 5,10, 20 or 100 random draws (results from these experiments are available on request). We are thus conservative in using a $\mathrm{K}$ as large as 20.

${ }^{9}$ We used this approach in a previous version of this paper and found results that are very similar to those reported here.
} 
The simpler correction for sample selection we use here consists in including people who never received UI in the sample. Although this cannot be done directly because of the data limitations mentioned above, some external data sources can be used to estimate the fraction of people who never received UI. More precisely, we use the 1981 Canadian Census to compute the total number of individuals who earned some labor income in 1980 by age, sex, and province of residence. We also use our merged T4-Status Vector file to calculate the corresponding number of individuals who worked in 1980 and received UI at least once between 1972 and 1992. We then use the two sets of numbers to compute an estimate of the fraction of all wage earners in 1980 who received UI at least once between 1972 and 1992. We finally use these estimated fractions to generate a random sample of non-UI recipients who look exactly like UI recipients except that we set their $U_{i t}$ 's to zero in all periods. We then maximize the log-likelihood function (5.7) over a sample composed of the subsample of UI-recipients who earned some wage income in 1980 and the "artificial" subsample of non-UI recipients who also earned some wage income in $1980 .^{10}$

A further advantage of the SML method is that it is straightforward to incorporate heterogeneity in other parameters than the intercept $\alpha$. Given the discussion in section 2, it seems natural to introduce heterogeneity in the learning parameter $\theta_{0}$ since a first experience with UI may have a larger effect for marginal workers than for non-marginal workers. To introduce heterogeneity in the learning parameter, write:

$$
\theta_{0 i}=\theta_{0}+\sigma \theta v_{i}
$$

where $v_{i}$ is a standard normal variable and $\sigma \theta$ is the standard deviation of $\theta_{0 i}$. The log-likelihood function can now be approximated by randomly drawing $\mathrm{K}$ values $\widetilde{u}_{i}^{1}, \ldots, \widetilde{u}_{i}^{K}$ of $u_{i}$ and $\mathrm{K}$ values $\widetilde{v}_{i}^{1}, \ldots, \widetilde{v}_{i}^{K}$ of $v_{i}$ :

$$
\begin{gathered}
\sum_{i=1}^{N} \log \left[\frac { 1 } { K } \sum _ { j = 1 } \left(\prod_{t=1}^{T} \Phi\left(\alpha+\delta_{t}+z_{i t}^{\prime} \omega+\sigma \alpha \tilde{u}^{j}+\sigma \theta \tilde{v}^{j} L_{i t}\right)^{\left(1-U_{i t}\right)}\right.\right. \\
\left.\left(1-\Phi\left(\alpha+\delta_{t}+z_{i t}^{\prime} \omega+\sigma \alpha \tilde{u}^{j}+\sigma \theta \tilde{v}^{j} L_{i t}\right)^{U_{i t}}\right)\right] .
\end{gathered}
$$

Note that $u_{i}$ and $v_{i}$ will be positively correlated if the learning effect and the probability of a first experience with UI are both larger for marginal than

\footnotetext{
${ }^{10}$ This procedure is still potentially biased since people must have worked in 1980 to enter the sample. The evidence presented in the previous version of this paper suggests, however, that this type of selection bias has only a small effect on the estimates.
} 
for non-marginal workers. Following Gourieroux and Monfort (1993), correlation between the heterogeneity in the learning effect and in the intercept is introduced by redefining $\theta_{0 i}$ as

$$
\theta_{0 i}=\theta_{0}+r_{1} u_{i}+r_{2} v_{i}
$$

where $r_{1}=\rho \sigma \theta / \sigma \alpha, r_{2}=\sqrt{\sigma \theta^{2}-\rho \sigma \theta / \sigma \alpha}, \rho$ is the correlation between the heterogeneity in the learning effect and in the intercept, and the error component $v_{i}$ is now defined as the part of the heterogeneity in the learning effect which is uncorrelated with the heterogeneity in the intercept. This model with correlated heterogeneity in the intercept and in the learning effect is easily estimated by replacing $\sigma \alpha \widetilde{u}^{j}+\sigma \theta \widetilde{v}^{j} L_{i t}$ with $\sigma \alpha \widetilde{u}^{j}+\left(r_{1} \widetilde{u}^{j}+r_{2} \widetilde{v}^{j}\right) L_{i t}$ in equation (5.8), drawing $\mathrm{K}$ independent values for both $\widetilde{u}^{j}$ and $\widetilde{v}^{j}$, and numerically maximizing the resulting log-likelihood function.

\subsection{Results}

Given the numerical burden associated with maximizing the log-likelihood function, we only perform the estimation over a randomly selected subsample of the main sample. In order to obtain estimates precise enough for several demographic groups in each province, we randomly select a 1-in-5 sample for Newfoundland, Nova Scotia, New Brunswick, and Saskatchewan, a 1-in-6 sample for Manitoba, a 1-in-8 sample for Alberta, a 1-in-20 sample for British Columbia, and a 1-in-50 sample for Quebec and Ontario. Prince Edward Island, Yukon and Northwest Territories are excluded from the estimation since these regions cannot be identified separately in the public use release of the 1981 Census micro data.

For both men and women in each province, we further divide the sample in three subsamples based on the year of birth. The first demographic subsample includes individuals born before 1946 who were all old enough to be in the labor force in 1972. The second sample is a sample of "baby-boomers" born from 1946 to 1955 while the third sample of individuals born after 1955 were unlikely to have entered the workforce in 1972 . We also limit our analysis to observations that satisfy the "eligibility" rule of having received some T4 income during the current or the previous year. Using this selection rule limits potential biases caused by people who permanently exit the labor force for various reasons. We have also estimated our models without this selection rule and found very similar results. 
We first estimate separate models for each of the six demographic groups (two genders and three cohorts) in each province. In each of the 54 random effect probit models, we include the learning variable, the first four lags of the dependent variable $\left(U_{i t-1}\right.$ to $\left.U_{i t-4}\right)$, a full set of year dummies, industry dummies, age and age squared. We decided to include four lags of the dependent variable after observing that the estimated effect of further lags was rarely statistically different from zero. Table 4 reports estimates from models in which unobserved heterogeneity is only included in the intercept. Unobserved heterogeneity is introduced in both the intercept and the learning coefficient in Table 5. We do not include any interactions between the learning variable and other variables in these simple models. The parameter $\theta_{1}$ is thus implicitly set to zero.

Estimates of the learning parameter $\theta_{0}$ are reported in Table $4 \mathrm{~A}$. While the estimated effect is on average positive, some interesting patterns seem to emerge from the Table. A first pattern is that learning effects tend to be large and positive for men born before 1946 but much smaller and often negative for women and younger men. In addition, learning effects are largest in Ontario, Saskatchewan, Alberta, and British Columbia, four provinces in which the use of UI is less pervasive than in the rest of the country.

These two patterns of results are consistent with the role of social versus individual learning mentioned earlier in the text. The more widespread the use of $\mathrm{UI}$ is in a region at a point of time, the less previous experience with UI will affect the propensity to use UI. The point is simply that when "everybody else" uses the system, a first experience with the system will not teach a person anything. he or she did not already know through family or friends. The results reported in Table $4 \mathrm{~A}$ thus support the view that younger cohorts of men and women living in areas where the use of UI is more wide spread already knew how the system worked before receiving UI for the first time. It is hard to see how other theories of occurrence dependence such as models of "addiction" or other sources of "vicious circles" could explain the pattern of results reported in Table 4A. For example, if people get addicted to UI in the way they get addicted to cigarette smoking, there is no reason why the effect of first time use of UI would vary across cohorts and regions. By contrast, the substitutability between individual and social learning provides a simple rationalization for the patterns observed in the data.

It is important to point out, however, that there is a lot of persistence in the propensity to use UI that has little to do with learning. The four lagged values of the dependent variable are positive and statistically significant for all demographic groups in all provinces. To give an idea of the magnitude of the effects, we report 
the sum of the estimated coefficients on the four lags of the dependent variable in Table 4B. The sum of these four coefficients is on average much larger than the size of the estimated learning effects. This suggests that labor market shocks can have relatively large effects on the propensity to use UI that will persist over several years.

The average learning effect becomes substantially larger when unobserved heterogeneity is also introduced in the learning effect in Table 5. In Table 5A, the average learning effect is positive for all provinces and all age groups. For all practical purpose, the estimated learning effect is positive for each individual demographic group in Ontario and in Western Canada. The results reported in Table $5 \mathrm{~A}$ thus reinforce our previous conclusion about the substitutability between individual and social learning. Note also that the sum of the coefficients on the four lags of the dependent variable is smaller in Table 5B than in Table 4B. There is also some variation in this sum across provinces and demographic groups, suggesting there may be problems in identifying the learning effect separately from the effect of the lags of the dependent variable.

We have thus re estimated a more constrained version of the model in which the lagged dependent variables as well as age and year dummies are constrained to have the same effect in the nine provinces. For each of the three groups of men and women, this constrained model is estimated on a pooled sample of the nine provincial samples used in Table 4 . We also include a set of province dummies to allow for differences in the intercept in each province.

One further advantage of working with a pooled sample is that we can exploit the variation of the parameters of the UI system over regions and over time to estimate the effect of these parameters on the propensity to use UI. We combine these UI parameters into a single "subsidy rate" of UI defined as the replacement rate multiplied by the ratio of the maximum number of weeks of eligibility of someone who has only worked the minimum number of weeks required to qualify over the minimum number of weeks to qualify. An increase in the subsidy rate tends to increase the size of the regions A and B in Figure 3. It should thus have a positive effect on the probability of receiving UI. One interesting hypothesis we can also test in this setting is whether the subsidy rate has a larger effect on people who had some previous experience with the UI system than on people who never had such experience. In terms of equation (5.1), this means that the component of the vector of parameters $\theta_{1}$ corresponding to the subsidy rate (one of the element of $x_{i t}$ ) should be positive. To insure that the estimated value of this parameter does not simply reflect omitted trends or regional differences in 
the size of the learning effect, we also interact the learning variable with the full set of year and province dummies.

The random effect probit estimates of the pooled models for men are reported in Table 6. The results for women are reported in Table 7 . In both cases, we estimate models with unobserved heterogeneity in both the intercept and the learning coefficient. Given the large number of parameter estimates reported in Tables 6 and 7, we only discuss few broad patterns in the results. The main conclusions that emerge from these Tables are:

1. With few exceptions, there is no longer much of a tendency for the learning effect to be smaller in the Maritimes and in Quebec than in other provinces. This means that the pattern found in Tables $5 \mathrm{~A}$ and $6 \mathrm{~A}$ may be a spurious consequence of the fact that it is hard to separately identify the learning effect from the effect of lags of the dependent variable. An alternative interpretation is that it is inappropriate to restrict the effect of lags of the dependent variable to be constant across provinces.

2. The subsidy rate always has a positive and significant effect on the probability of receiving UI. These effects are quite small, however, in economic terms. According to the parameter estimates, the impact of a 100 percent increase in the subsidy rate on the probability of receiving UI is 2 to 3 percentage points for most of the estimated specifications. The effect of the subsidy rate does not tend to be systematically larger, however, for individuals who have been exposed to UI in the past than for individuals who have not been exposed.

3. There is no systematic pattern in the learning effect over time except for the cohort born in 1946-55 for which it trends upward.

4. The variance of the heterogeneity components is significantly larger than zero in most of the specifications. Furthermore, the error components reflecting heterogeneity in the intercept and in the learning effect are positively correlated for men. This is consistent with the simple model of employment and unemployment presented in Section 2 (the probability of receiving UI for a first time and the effect of a first exposure are both larger for marginal than for non-marginal workers. This correlation is negative, however, for older cohorts of women but tends to become more positive for younger cohorts. We thus conjecture that the negative correlation is due to differences in labor force participation behavior of older cohorts of men and women. 
Taken together, the results reported in Tables 4 to 7 suggest that one's first experience with UI has a permanent effect on the future probability of receiving UI. This is especially clear for older cohorts of men. This pattern of results is partly consistent with the idea that individual or social learning about the parameters of the UI system has an impact on employment and unemployment behavior. It could also be consistent, however, with other sources of "hysteresis" coming from the supply side of the market.

\section{Summary of the Findings and Concluding Remarks}

We find that first time use of the unemployment insurance system in Canada increases the probability of future use. This effect is a potential explanation for the increasing share of UI spells accounted by repeated users ${ }^{11}$. As workers are exposed to UI for the first time for a variety of reasons, they learn about the functioning of the system and adjust their behavior accordingly. For high skill workers, this first exposure to the system will not affect their behavior very much since it is not profiTable for them to work part-year except perhaps during a short adjustment period. By contrast, for less skilled workers working part-year may be an attractive long run option. For these workers, a first experience may thus have a large effect on the future probability of receiving UI.

We also find some support for the view that the effect of first time use is a learning effect since the estimated effect tends to be lower for people who are more likely to know how the UI system operates (young workers and people living in high unemployment regions). We also find that adjustment lags over several period account for an important part of the dynamics in UI recipiency.

In this framework, the evolution of UI recipiency over time depends jointly on the evolution of the employment and income process and on the evolution of the probability of receiving UI conditional on being eligible (the take-up rate). In future research, it would interesting to see how the dynamics of UI recipiency can be broken up into these two components.

Though we have only reduced form results they do have some potentially important implications of the design of social welfare programs. First, the behavior that we have observed is consistent with individuals responding to the incentives provided by the system. The fact that experience is required for a change in behavior is consistent with laboratory studies of learning. It also suggests that

\footnotetext{
${ }^{11}$ See Lemieux and MacLeod (1995) for evidence on the distribution of UI recipients by frequency of use.
} 
studies based on cross-section estimates of supply responses underestimate the long term impact of the disincentive effects of social welfare programs.

Secondly, it highlights the importance of coverage in determining the impact of changes in a program. Rule changes that effect current recipients can be expected to have an immediate impact because the individuals experience the rule change. However for program rule changes that involve an increase in the target population our results suggest that it may take some time before the new individuals at risk respond fully to the new incentives. In summary these results suggest that great care must be taken if we are to properly interpret the relationship between changes in incentives at the individual level, and the subsequent impact on the economy as a whole.

\section{References}

Blanchard, Olivier and Juan F. Jimeno, "Structural Unemployment: Spain versus Portugal," American Economic Review, May 1995, 85 (2), 212-218.

Card, David and W. Craig Ridell, "A Comparative Analysis of Unemployment in the United States and Canada," in Davie Card and Richard H. Freeman, eds., Small Differences that Matter: Labor Markets and Income Maintenance in Canada and the United States, Chicago, IL: University of Chicago Press, 1993.

Corak, Miles, "Unemployment Insurance Once Again: The Incidence of Repeat Participation in the Canadian UI Program," Canadian Public Policy, June 1993, 19 (2), 162-176.

Gourieroux, Christian and Alan Monfort, "Simulation-Based Inference: A Survey with Special Reference to Panel Data Models," Journal of Econometrics, 1993, 59, 5-34.

Green, David A. and W. Craig Riddell, "The Economic Effect of Unemployment Insurance in Canada: An Empirical Analysis of UI Disentitlement," Journal of Labor Economics, January 1993, 11, S96-S147.

Ham, John and Samuel Rea, "Journal of Labor Economics," July 1987, 5, $325-351$. 
Heckman, James J., "Simple Statistical Models for Discrete Panel Data Developed and Applied to Test the Hypothesis of True State Dependence Against the Hypothesis of Spurious State Dependence," Annales de l'INSEE, 1978, 30, $227-269$.

_ "The Incidental Parameters Problem and the Problem of Initial Conditions in Estimating a Discrete Time-Discrete Data Stochastic Process," in Charles F. Manski and Daniel McFadden, eds., Structural Analysis of Discrete Data with Econometric Applications, Cambridge, MA: MIT Press, 1981.

, "Statistical Models for Discrete Panel Data," in Charles F. Manski and Daniel McFadden, eds., Structural Analysis of Discrete Data with Econometric Applications, Cambridge, MA: MTT Press, 1981.

and George Borjas, "Does Unemployment cause future unemployment? Definitions, questions and answers from a continuous time model of heterogeneity and state dependence.," Economica, 1980, pp. 247-283.

Katz, Lawrence F. and Bruce D. Meyer, "Unemployment Insurance, Recall Expectations, and Unemployment Outcomes," Quarterly Journal of Economics, November 1990, 105 (4), 973-1002.

Layard, Richard, Stephen Nickell, and Richard Jackman, Unemployment:Macroeconomic Performance and the Labour Market, Oxford, UK: Oxford University Press, 1991.

Lehman, S.R. and Charles F. Manski, "On the Use of Simulated Frequencies to Approximate Choice Probabilities," in Charles F. Manski and Daniel McFadden, eds., Structural Analysis of Discrete Data with Econometric Applications, Cambridge, MA: MTT Press, 1981.

Lemieux, Thomas and W. Bentley MacLeod, "State Dependence and Unemployment Insurance," Technical Report 4, Human Resources Development Canada 1995.

Lindbeck, Assar, "Welfare State Disincentives with Endogenous Habits and Norms," Scandinavian Journal of Economics, December 1995, 97 (4), 477494.

Meyer, Bruce, "Unemployment Insurance and Unemployment Spells," Econometrica, July 1990, 58, 757-782. 
Meyer, Bruce D. and Dan T. Resenbaum, "Repeat Use of Unemployment Insurance," December 1995. mimeo, Northwestern University, Evanston, Il.

Moffitt, Robert, "Incentive Effects of the U.S. Welfare System: A Review," Journal of Economic Literature, March 1992, 30 (1), 1-61.

Skinner, B. F., Science and Human Behavior, New York, N.Y.: The Macmillan Company, 1953.

Topel, Robert H., "On Layoffs and Unemployment Insurance," American Economic Review, September 1983, 73, 541-559.

Wickens, Christopher, Engineering Psychology and Human Performance, 2nd ed., New York, N.Y.: HarperCollins Publishers Inc., 1992. 


\begin{tabular}{|c|c|c|c|c|c|}
\hline \multirow[b]{2}{*}{ Age } & \multicolumn{3}{|l|}{ Age of Entry } & \multicolumn{2}{|l|}{ Year of Entry } \\
\hline & Frequency & Cumul. freq. & $\underline{\text { Year }}$ & Frequency & Cumul. freq. \\
\hline 15 & 0.105 & 0.105 & 1972 & 0.493 & 0.493 \\
\hline 16 & 0.124 & 0.229 & 1973 & 0.061 & 0.553 \\
\hline 17 & 0.110 & 0.339 & 1974 & 0.049 & 0.602 \\
\hline 18 & 0.079 & 0.418 & 1975 & 0.038 & 0.640 \\
\hline 19 & 0.049 & 0.466 & 1976 & 0.035 & 0.675 \\
\hline 20 & 0.035 & 0.501 & 1977 & 0.034 & 0.709 \\
\hline 21 & 0.029 & 0.531 & 1978 & 0.033 & 0.742 \\
\hline 22 & 0.026 & 0.557 & 1979 & 0.034 & 0.776 \\
\hline 23 & 0.025 & 0.582 & 1980 & 0.031 & 0.807 \\
\hline 24 & 0.024 & 0.606 & 1981 & 0.030 & 0.837 \\
\hline 25 & 0.023 & 0.629 & 1982 & 0.020 & 0.857 \\
\hline 26 & 0.020 & 0.649 & 1983 & 0.022 & 0.879 \\
\hline 27 & 0.019 & 0.668 & 1984 & 0.023 & 0.902 \\
\hline 28 & 0.018 & 0.685 & 1985 & 0.023 & 0.925 \\
\hline 29 & 0.017 & 0.702 & 1986 & 0.021 & 0.946 \\
\hline $30-34$ & 0.069 & 0.771 & 1987 & 0.021 & 0.967 \\
\hline $35-39$ & 0.057 & 0.828 & 1988 & 0.013 & 0.981 \\
\hline $40-44$ & 0.055 & 0.883 & 1989 & 0.010 & 0.991 \\
\hline $45-49$ & 0.049 & 0.932 & 1990 & 0.006 & 0.996 \\
\hline $50-54$ & 0.038 & 0.970 & 1991 & 0.004 & 1.000 \\
\hline $55-59$ & 0.025 & 0.995 & & & \\
\hline $60-64$ & 0.005 & 1.000 & & & \\
\hline
\end{tabular}

Note: Based on a sample of 618,911 men aged 15 to 65 . A person "enters" the sample the first time he receives T4 income between 1972 and 1991. 


\begin{tabular}{|c|c|c|}
\hline & Mean & Proportion starting a UI claim \\
\hline Age: & 34.759 & --- \\
\hline $\begin{array}{l}\text { Employed during } \\
\text { the year: }\end{array}$ & 0.796 & --- \\
\hline Ul claim: & 0.210 & --- \\
\hline \multicolumn{3}{|l|}{ Province: } \\
\hline Newfounland & 0.025 & 0.375 \\
\hline PEI & 0.005 & 0.349 \\
\hline Nova Scotia & 0.036 & 0.259 \\
\hline New Brunswick & 0.031 & 0.321 \\
\hline Quebec & 0.286 & 0.234 \\
\hline Ontario & 0.350 & 0.179 \\
\hline Manitoba & 0.037 & 0.185 \\
\hline Saskatchewan & 0.029 & 0.196 \\
\hline Alberta & 0.087 & 0.176 \\
\hline British Columbia & 0.115 & 0.194 \\
\hline \multicolumn{3}{|l|}{ Year: } \\
\hline 1972 & 0.030 & 0.234 \\
\hline 1973 & 0.033 & 0.205 \\
\hline 1974 & 0.036 & 0.204 \\
\hline 1975 & 0.038 & 0.238 \\
\hline 1976 & 0.041 & 0.216 \\
\hline 1977 & 0.043 & 0.221 \\
\hline 1978 & 0.044 & 0.215 \\
\hline 1979 & 0.046 & 0.180 \\
\hline 1980 & 0.048 & 0.183 \\
\hline 1981 & 0.049 & 0.198 \\
\hline 1982 & 0.050 & 0.267 \\
\hline 1983 & 0.051 & 0.230 \\
\hline 1984 & 0.052 & 0.225 \\
\hline 1985 & 0.053 & 0.204 \\
\hline 1986 & 0.054 & 0.199 \\
\hline 1987 & 0.055 & 0.183 \\
\hline 1988 & 0.055 & 0.182 \\
\hline 1989 & 0.055 & 0.190 \\
\hline 1990 & 0.055 & 0.215 \\
\hline 1991 & 0.055 & 0.222 \\
\hline 1992 & 0.054 & 0.214 \\
\hline
\end{tabular}

Note: Based on a sample of $10,253,535$ observations of men aged 15 to 65 from the years 1972 to 1992 who have earned some T4 income at least once since 1972. 


\section{Table 3: Autocorrelation in the Use of Unemployment Insurance over Time}

\begin{tabular}{lccc}
\hline \hline Time Interval: & Correlation: & Time Interval: & Correlation: \\
\cline { 2 - 3 } Same year & 1.000 & & \\
1 year & 0.291 & 11 year & 0.108 \\
2 years & 0.280 & 12 years & 0.100 \\
3 years & 0.243 & 13 years & 0.090 \\
4 years & 0.215 & 14 years & 0.082 \\
5 years & 0.190 & 15 years & 0.070 \\
6 years & 0.175 & 16 years & 0.063 \\
7 years & 0.158 & 17 years & 0.051 \\
8 years & 0.142 & 18 years & 0.044 \\
9 years & 0.127 & 19 years & 0.032 \\
10 years & 0.116 & 20 years & 0.026 \\
\hline
\end{tabular}

Note: These correlations are calculated from a sample of 604,185 observations on men born in the years 1931, 1941, and 1951. 
Table 4: Grouped Data Estimates of the Effect of Learning on the Future Probability of Receiving Unemployment Insurance

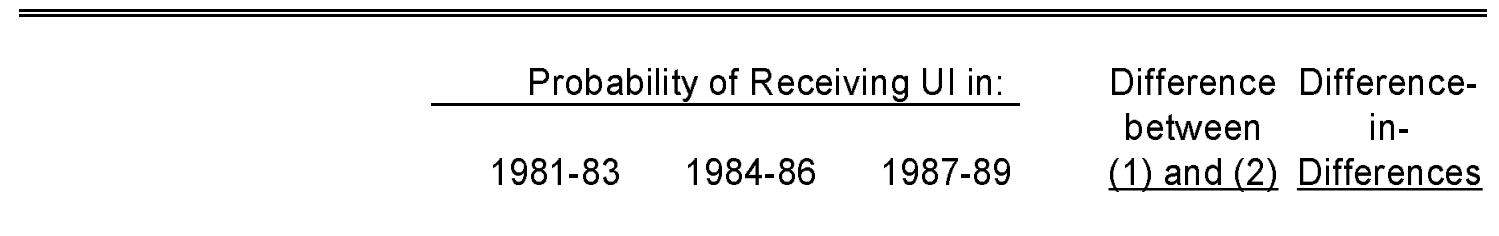

(1)

(2)

(3)

(4)

(5)

1. Men born in 1931

1.a. Had no previous

0.355

0.373

0.345

0.019

UI experience

1.b. Had some previous

0.432

0.328

0.260

$-0.104$

Ul experience

2. Men born in 1941

2.a. Had no previous

0.406

0.365

0.330

$-0.041$

UI experience

2.b. Had some previous

0.436

0.353

0.295

$-0.083$

UI experience

3. Men born in 1951

3.a. Had no previous

Ul experience

0.421

0.395

0.325

$-0.026$

0.042

3.b. Had some previous

0.412

0.330

0.269

$-0.082$

Ul experience

B. Adjusted for selection

1. Men born in 1931

1.a. Had no previous

$0.2119514 \quad 0.2567694 \quad 0.3109244$

0.045

UI experience

1.b. Had some previous $0.6806551 \quad 0.6427840 .6489253$

$-0.038$

UI experience

2. Men born in 1941

2.a. Had no previous

UI experience

$0.250655 \quad 0.2707424 \quad 0.3379913$

0.020

0.056

0.123

2.b. Had some previous $0.6756757 \quad 0.6313974 \quad 0.6354227$

$-0.044$

UI experience

3. Men born in 1951

$\begin{array}{lllll}\text { 3.a. Had no previous } & 0.2752355 & 0.2960969 & 0.3304172 & 0.021\end{array}$

Ul experience

0.071

3.b. Had some previous $0.6510591 \quad 0.60061320 .6042363$

$-0.050$ UI experience 


\section{Table 5A: Random Effect Probit Estimates of the Learning Effect}

by Demographic Group and by Province, 1972-1992:

Unobserved (normal) heterogeneity in intercept only

\begin{tabular}{|c|c|c|c|c|c|c|c|}
\hline \multirow{3}{*}{ Province } & \multicolumn{2}{|c|}{ "Born before 1946} & \multicolumn{2}{|c|}{ Born from 1946 to 1955} & \multicolumn{2}{|c|}{ Born after 1955} & \multirow{3}{*}{$\begin{array}{c}\text { Average } \\
(7)\end{array}$} \\
\hline & Men & Women & Men & Women & Men & $\underline{\text { Women }}$ & \\
\hline & (1) & (2) & (3) & (4) & (5) & (6) & \\
\hline Newfoundland & $\begin{array}{c}0.548 \\
(0.047)\end{array}$ & $\begin{array}{c}0.165 \\
(0.075)\end{array}$ & $\begin{array}{c}0.117 \\
(0.050)\end{array}$ & $\begin{array}{c}-0.153 \\
(0.063)\end{array}$ & $\begin{array}{l}-0.411 \\
(0.052)\end{array}$ & $\begin{array}{l}-0.437 \\
(0.056)\end{array}$ & -0.028 \\
\hline Nova Scotia & $\begin{array}{c}0.481 \\
(0.040)\end{array}$ & $\begin{array}{c}0.097 \\
(0.055)\end{array}$ & $\begin{array}{c}0.100 \\
(0.042)\end{array}$ & $\begin{array}{c}0.011 \\
(0.052)\end{array}$ & $\begin{array}{l}-0.304 \\
(0.039)\end{array}$ & $\begin{array}{l}-0.252 \\
(0.049)\end{array}$ & 0.022 \\
\hline New Brunswick & $\begin{array}{c}0.471 \\
(0.044)\end{array}$ & $\begin{array}{c}0.014 \\
(0.065)\end{array}$ & $\begin{array}{l}-0.072 \\
(0.045)\end{array}$ & $\begin{array}{l}-0.158 \\
(0.056)\end{array}$ & $\begin{array}{l}-0.303 \\
(0.044)\end{array}$ & $\begin{array}{l}-0.289 \\
(0.050)\end{array}$ & -0.056 \\
\hline Quebec & $\begin{array}{c}0.225 \\
(0.046)\end{array}$ & $\begin{array}{c}0.134 \\
(0.055)\end{array}$ & $\begin{array}{l}-0.054 \\
(0.045)\end{array}$ & $\begin{array}{c}0.105 \\
(0.053)\end{array}$ & $\begin{array}{l}-0.257 \\
(0.045)\end{array}$ & $\begin{array}{l}-0.091 \\
(0.053)\end{array}$ & 0.010 \\
\hline Ontario & $\begin{array}{c}0.437 \\
(0.034)\end{array}$ & $\begin{array}{c}0.130 \\
(0.040)\end{array}$ & $\begin{array}{c}0.034 \\
(0.040)\end{array}$ & $\begin{array}{c}0.010 \\
(0.046)\end{array}$ & $\begin{array}{l}-0.055 \\
(0.037)\end{array}$ & $\begin{array}{c}0.002 \\
(0.046)\end{array}$ & 0.093 \\
\hline Manitoba & $\begin{array}{c}0.403 \\
(0.038)\end{array}$ & $\begin{array}{c}0.094 \\
(0.046)\end{array}$ & $\begin{array}{l}-0.037 \\
(0.042)\end{array}$ & $\begin{array}{r}-0.064 \\
0.052\end{array}$ & $\begin{array}{l}-0.056 \\
(0.038)\end{array}$ & $\begin{array}{l}-0.034 \\
(0.052)\end{array}$ & 0.051 \\
\hline Saskatchewan & $\begin{array}{c}0.512 \\
(0.037)\end{array}$ & $\begin{array}{c}0.129 \\
(0.056)\end{array}$ & $\begin{array}{c}0.149 \\
(0.047)\end{array}$ & $\begin{array}{l}-0.064 \\
(0.061)\end{array}$ & $\begin{array}{c}0.042 \\
(0.035)\end{array}$ & $\begin{array}{c}0.050 \\
(0.047)\end{array}$ & 0.136 \\
\hline Alberta & $\begin{array}{c}0.505 \\
(0.044)\end{array}$ & $\begin{array}{c}0.242 \\
(0.053)\end{array}$ & $\begin{array}{c}0.409 \\
(0.046)\end{array}$ & $\begin{array}{c}0.249 \\
(0.057)\end{array}$ & $\begin{array}{c}0.409 \\
(0.038)\end{array}$ & $\begin{array}{c}0.355 \\
(0.047)\end{array}$ & 0.361 \\
\hline British Columbia & $\begin{array}{c}0.464 \\
(0.037)\end{array}$ & $\begin{array}{c}0.136 \\
(0.053)\end{array}$ & $\begin{array}{c}0.187 \\
(0.045)\end{array}$ & $\begin{array}{c}0.208 \\
(0.052)\end{array}$ & $\begin{array}{l}-0.007 \\
(0.041)\end{array}$ & $\begin{array}{l}-0.037 \\
(0.051)\end{array}$ & 0.158 \\
\hline Average & 0.449 & 0.127 & 0.093 & 0.016 & -0.105 & -0.082 & 0.083 \\
\hline
\end{tabular}

Note: $\quad$ Standard errors are in parentheses. All models also include

a full set of year effects, four lagged values of the dependent

variable, age and its squared, and nine industry dummies. Unobserved

heterogeneity is accounted for by including a standard normal component in

the intercept and estimating the model using simulated

maximum likelihood (20 draws). 
Table 5B: Sum of the Estimated Coefficients on the Four Lags of the Dependent Variable by Demographic Group and by Province.

\begin{tabular}{|c|c|c|c|c|c|c|c|}
\hline \multirow[b]{2}{*}{ Province } & \multicolumn{2}{|c|}{ Born before 1946} & \multicolumn{2}{|c|}{ Born from 1946 to 1955} & \multicolumn{2}{|c|}{ Born after 1955} & \multirow{3}{*}{$\begin{array}{c}\text { Average } \\
(7)\end{array}$} \\
\hline & Men & Women & Men & Women & Men & Women & \\
\hline & (1) & (2) & (3) & (4) & (5) & (6) & \\
\hline Newfoundland & 1.345 & 1.415 & 1.400 & 1.618 & 1.580 & 1.555 & 1.441 \\
\hline Nova Scotia & 1.572 & 1.634 & 1.436 & 1.483 & 1.355 & 1.383 & 1.454 \\
\hline New Brunswick & 1.728 & 1.798 & 1.591 & 1.631 & 1.349 & 1.390 & 1.556 \\
\hline Quebec & 1.390 & 1.396 & 1.296 & 1.252 & 1.388 & 1.306 & 1.358 \\
\hline Ontario & 1.484 & 1.622 & 1.182 & 1.284 & 1.188 & 1.166 & 1.285 \\
\hline Manitoba & 1.765 & 1.809 & 1.334 & 1.366 & 1.203 & 1.122 & 1.434 \\
\hline Saskatchewan & 1.927 & 1.946 & 1.444 & 1.373 & 1.305 & 1.146 & 1.559 \\
\hline Alberta & 1.500 & 1.503 & 1.348 & 1.422 & 1.101 & 0.995 & 1.317 \\
\hline British Columbia & 1.399 & 1.469 & 1.261 & 1.324 & 0.988 & 0.970 & 1.216 \\
\hline Average & 1.568 & 1.621 & 1.366 & 1.417 & 1.273 & 1.226 & 1.402 \\
\hline
\end{tabular}

Note: $\quad$ See the note at the bottom of Table $5 \mathrm{~A}$ for more information on the estimated models. 
Table 5C: Number of Observations and Persons Used in the Estimation

\begin{tabular}{|c|c|c|c|c|c|c|}
\hline \multirow{3}{*}{ Province } & \multicolumn{2}{|c|}{ Born before 1946} & \multicolumn{2}{|c|}{ Born from 1946 to 1955} & \multicolumn{2}{|c|}{ Born after 1955} \\
\hline & Men & Women & Men & Women & Men & Women \\
\hline & (1) & (2) & (3) & (4) & (5) & (6) \\
\hline Newfoundland & $\begin{array}{r}19047 \\
(1087)\end{array}$ & $\begin{array}{l}8606 \\
(544)\end{array}$ & $\begin{array}{r}16843 \\
(846)\end{array}$ & $\begin{array}{l}9592 \\
(530)\end{array}$ & $\begin{array}{r}11788 \\
(723)\end{array}$ & $\begin{array}{l}8383 \\
(548)\end{array}$ \\
\hline Nova Scotia & $\begin{array}{l}34682 \\
(2018)\end{array}$ & $\begin{array}{r}18293 \\
(1161)\end{array}$ & $\begin{array}{l}24056 \\
(1233)\end{array}$ & $\begin{array}{r}15847 \\
(879)\end{array}$ & $\begin{array}{r}18742 \\
(1175)\end{array}$ & $\begin{array}{c}15252 \\
(1024)\end{array}$ \\
\hline New Brunswick & $\begin{array}{l}25466 \\
(1488)\end{array}$ & $\begin{array}{r}14061 \\
(893)\end{array}$ & $\begin{array}{r}19236 \\
(976)\end{array}$ & $\begin{array}{r}12576 \\
(691)\end{array}$ & $\begin{array}{r}15588 \\
(957)\end{array}$ & $\begin{array}{r}11845 \\
(789)\end{array}$ \\
\hline Quebec & $\begin{array}{l}27120 \\
(1558)\end{array}$ & $\begin{array}{r}15250 \\
(962)\end{array}$ & $\begin{array}{r}18678 \\
(961)\end{array}$ & $\begin{array}{r}13008 \\
(712)\end{array}$ & $\begin{array}{r}13972 \\
(859)\end{array}$ & $\begin{array}{r}11098 \\
(735)\end{array}$ \\
\hline Ontario & $\begin{array}{l}39187 \\
(2282)\end{array}$ & $\begin{array}{l}26842 \\
(1623)\end{array}$ & $\begin{array}{l}25005 \\
(1291)\end{array}$ & $\begin{array}{l}19600 \\
(1066)\end{array}$ & $\begin{array}{l}20226 \\
(1251)\end{array}$ & $\begin{array}{r}18039 \\
(548)\end{array}$ \\
\hline Manitoba & $\begin{array}{l}32750 \\
(1950)\end{array}$ & $\begin{array}{l}23373 \\
(1462)\end{array}$ & $\begin{array}{l}22553 \\
(1166)\end{array}$ & $\begin{array}{r}17383 \\
(947)\end{array}$ & $\begin{array}{l}20101 \\
(1265)\end{array}$ & $\begin{array}{l}17245 \\
(1131)\end{array}$ \\
\hline Saskatchewan & $\begin{array}{l}28322 \\
(1714)\end{array}$ & $\begin{array}{l}23248 \\
(1437)\end{array}$ & $\begin{array}{l}22793 \\
(1188)\end{array}$ & $\begin{array}{r}15783 \\
(850)\end{array}$ & $\begin{array}{l}23305 \\
(1471)\end{array}$ & $\begin{array}{l}18441 \\
(1208)\end{array}$ \\
\hline Alberta & $\begin{array}{l}36200 \\
(2123)\end{array}$ & $\begin{array}{l}23558 \\
(1448)\end{array}$ & $\begin{array}{l}31299 \\
(1645)\end{array}$ & $\begin{array}{l}21736 \\
(1191)\end{array}$ & $\begin{array}{l}29090 \\
(1789)\end{array}$ & $\begin{array}{l}23714 \\
(1532)\end{array}$ \\
\hline British Columbia & $\begin{array}{l}30826 \\
(1795)\end{array}$ & $\begin{array}{l}20017 \\
(1244)\end{array}$ & $\begin{array}{l}21232 \\
(1114)\end{array}$ & $\begin{array}{r}15903 \\
(885)\end{array}$ & $\begin{array}{l}16869 \\
(1057)\end{array}$ & $\begin{array}{r}13995 \\
(924)\end{array}$ \\
\hline
\end{tabular}

Note: $\quad$ The number of indiduals in each subsample is in parentheses. 
Table 6A: Random Effect Probit Estimates of the Learning Effect by Demographic Group and by Province, 1972-1992:

Unobserved (normal) heterogeneity in intercept and learning coefficient

\begin{tabular}{|c|c|c|c|c|c|c|c|}
\hline \multirow{3}{*}{ Province } & \multicolumn{2}{|c|}{ "Born before 1946} & \multicolumn{2}{|c|}{ Born from 1946 to 1955} & \multicolumn{2}{|c|}{ Born after 1955} & \multirow{3}{*}{$\begin{array}{c}\text { Average } \\
(7)\end{array}$} \\
\hline & Men & Women & Men & Women & Men & $\underline{\text { Women }}$ & \\
\hline & (1) & (2) & (3) & (4) & (5) & (6) & \\
\hline Newfoundland & $\begin{array}{c}0.548 \\
(0.047)\end{array}$ & $\begin{array}{c}0.165 \\
(0.075)\end{array}$ & $\begin{array}{c}0.117 \\
(0.051)\end{array}$ & $\begin{array}{c}-0.153 \\
(0.063)\end{array}$ & $\begin{array}{l}-0.411 \\
(0.052)\end{array}$ & $\begin{array}{l}-0.437 \\
(0.056)\end{array}$ & -0.028 \\
\hline Nova Scotia & $\begin{array}{c}0.713 \\
(0.040)\end{array}$ & $\begin{array}{c}0.078 \\
(0.055)\end{array}$ & $\begin{array}{c}0.168 \\
(0.049)\end{array}$ & $\begin{array}{l}-0.028 \\
(0.071)\end{array}$ & $\begin{array}{l}-0.138 \\
(0.048)\end{array}$ & $\begin{array}{l}-0.235 \\
(0.055)\end{array}$ & 0.093 \\
\hline New Brunswick & $\begin{array}{c}0.438 \\
(0.048)\end{array}$ & $\begin{array}{l}-0.034 \\
(0.062)\end{array}$ & $\begin{array}{c}0.034 \\
(0.057)\end{array}$ & $\begin{array}{l}-0.336 \\
(0.075)\end{array}$ & $\begin{array}{l}-0.221 \\
(0.057)\end{array}$ & $\begin{array}{l}-0.309 \\
(0.068)\end{array}$ & -0.071 \\
\hline Quebec & $\begin{array}{c}0.647 \\
(0.044)\end{array}$ & $\begin{array}{c}0.104 \\
(0.060)\end{array}$ & $\begin{array}{c}0.056 \\
(0.054)\end{array}$ & $\begin{array}{c}0.117 \\
(0.074)\end{array}$ & $\begin{array}{l}-0.154 \\
(0.060)\end{array}$ & $\begin{array}{c}0.022 \\
(0.065)\end{array}$ & 0.132 \\
\hline Ontario & $\begin{array}{c}0.598 \\
(0.035)\end{array}$ & $\begin{array}{c}0.271 \\
(0.041)\end{array}$ & $\begin{array}{c}0.129 \\
(0.046)\end{array}$ & $\begin{array}{c}0.097 \\
(0.057)\end{array}$ & $\begin{array}{c}0.023 \\
(0.047)\end{array}$ & $\begin{array}{c}0.117 \\
(0.046)\end{array}$ & 0.206 \\
\hline Manitoba & $\begin{array}{c}0.578 \\
(0.044)\end{array}$ & $\begin{array}{c}0.343 \\
(0.058)\end{array}$ & $\begin{array}{c}0.066 \\
(0.047)\end{array}$ & $\begin{array}{c}0.093 \\
(0.057)\end{array}$ & $\begin{array}{c}0.139 \\
(0.049)\end{array}$ & $\begin{array}{c}0.205 \\
(0.056)\end{array}$ & 0.237 \\
\hline Saskatchewan & $\begin{array}{c}0.591 \\
(0.052)\end{array}$ & $\begin{array}{c}0.174 \\
(0.062)\end{array}$ & $\begin{array}{c}0.399 \\
(0.051)\end{array}$ & $\begin{array}{l}-0.009 \\
(0.075)\end{array}$ & $\begin{array}{c}0.016 \\
(0.046)\end{array}$ & $\begin{array}{c}0.253 \\
(0.058)\end{array}$ & 0.237 \\
\hline Alberta & $\begin{array}{c}0.757 \\
(0.057)\end{array}$ & $\begin{array}{c}0.235 \\
(0.065)\end{array}$ & $\begin{array}{c}0.786 \\
(0.058)\end{array}$ & $\begin{array}{c}0.744 \\
(0.086)\end{array}$ & $\begin{array}{c}0.510 \\
(0.043)\end{array}$ & $\begin{array}{c}0.499 \\
(0.064)\end{array}$ & 0.588 \\
\hline British Columbia & $\begin{array}{c}0.720 \\
(0.045)\end{array}$ & $\begin{array}{c}0.410 \\
(0.061)\end{array}$ & $\begin{array}{c}0.352 \\
(0.053)\end{array}$ & $\begin{array}{c}0.440 \\
(0.059)\end{array}$ & $\begin{array}{c}0.035 \\
(0.054)\end{array}$ & $\begin{array}{c}0.040 \\
(0.067)\end{array}$ & 0.333 \\
\hline Average & 0.621 & 0.194 & 0.234 & 0.107 & -0.022 & 0.017 & 0.192 \\
\hline
\end{tabular}

Note: $\quad$ Standard errors are in parentheses. All models also include a full set of year effects, four lagged values of the dependent variable, age and its squared, and nine industry dummies. Unobserved heterogeneity is accounted for by including a standard normal component in the intercept and the learning coefficient and estimating the model using simulated maximum likelihood (20 draws). 
Table 6B: Sum of the Estimated Coefficients on the Four Lags of the Dependent Variable by Demographic Group and by Province.

\begin{tabular}{|c|c|c|c|c|c|c|c|}
\hline \multirow[b]{2}{*}{ Province } & \multicolumn{2}{|c|}{ Born before 1946} & \multicolumn{2}{|c|}{ Born from 1946 to 1955} & \multicolumn{2}{|c|}{ Born after 1955} & \multirow{3}{*}{$\begin{array}{c}\text { Average } \\
(7)\end{array}$} \\
\hline & Men & Women & Men & Women & $\underline{\text { Men }}$ & Women & \\
\hline & (1) & (2) & (3) & (4) & (5) & (6) & \\
\hline Newfoundland & 1.253 & 1.358 & 1.379 & 1.611 & 1.586 & 1.550 & 1.406 \\
\hline Nova Scotia & 1.513 & 1.718 & 1.300 & 1.481 & 1.155 & 1.300 & 1.323 \\
\hline New Brunswick & 1.743 & 1.926 & 1.355 & 1.550 & 1.214 & 1.297 & 1.437 \\
\hline Quebec & 1.337 & 1.469 & 1.143 & 1.198 & 1.231 & 1.222 & 1.237 \\
\hline Ontario & 1.320 & 1.470 & 1.042 & 1.211 & 1.038 & 1.006 & 1.133 \\
\hline Manitoba & 1.488 & 1.510 & 1.210 & 1.246 & 0.962 & 0.856 & 1.220 \\
\hline Saskatchewan & 1.683 & 1.824 & 1.436 & 1.409 & 1.218 & 1.039 & 1.445 \\
\hline Alberta & 1.141 & 1.305 & 1.208 & 1.261 & 0.910 & 0.790 & 1.087 \\
\hline British Columbia & 1.068 & 1.194 & 1.025 & 1.093 & 0.846 & 0.881 & 0.979 \\
\hline Average & 1.394 & 1.530 & 1.233 & 1.340 & 1.129 & 1.105 & 1.252 \\
\hline
\end{tabular}

Note: $\quad$ See the note at the bottom of Table $6 \mathrm{~A}$ for more information on the estimated models. 
Table 6C: Number of Observations and Persons Used in the Estimation

\begin{tabular}{|c|c|c|c|c|c|c|}
\hline \multirow{3}{*}{ Province } & \multicolumn{2}{|c|}{ Born before 1946} & \multicolumn{2}{|c|}{ Born from 1946 to 1955} & \multicolumn{2}{|c|}{ Born after 1955} \\
\hline & $\underline{\text { Men }}$ & Women & Men & Women & Men & Women \\
\hline & (1) & (2) & (3) & (4) & (5) & (6) \\
\hline Newfoundland & $\begin{array}{r}19047 \\
(1087)\end{array}$ & $\begin{array}{l}8606 \\
(544)\end{array}$ & $\begin{array}{r}16843 \\
(846)\end{array}$ & $\begin{array}{l}9592 \\
(530)\end{array}$ & $\begin{array}{r}11788 \\
(723)\end{array}$ & $\begin{array}{l}8383 \\
(548)\end{array}$ \\
\hline Nova Scotia & $\begin{array}{l}34682 \\
(2018)\end{array}$ & $\begin{array}{c}18293 \\
(1161)\end{array}$ & $\begin{array}{l}24056 \\
(1233)\end{array}$ & $\begin{array}{r}15847 \\
(879)\end{array}$ & $\begin{array}{r}18742 \\
(1175)\end{array}$ & $\begin{array}{c}15252 \\
(1024)\end{array}$ \\
\hline New Brunswick & $\begin{array}{l}25466 \\
(1488)\end{array}$ & $\begin{array}{r}14061 \\
(893)\end{array}$ & $\begin{array}{r}19236 \\
(976)\end{array}$ & $\begin{array}{r}12576 \\
(691)\end{array}$ & $\begin{array}{r}15588 \\
(957)\end{array}$ & $\begin{array}{r}11845 \\
(789)\end{array}$ \\
\hline Quebec & $\begin{array}{l}27120 \\
(1558)\end{array}$ & $\begin{array}{r}15250 \\
(962)\end{array}$ & $\begin{array}{r}18678 \\
(961)\end{array}$ & $\begin{array}{r}13008 \\
(712)\end{array}$ & $\begin{array}{r}13972 \\
(859)\end{array}$ & $\begin{array}{r}11098 \\
(735)\end{array}$ \\
\hline Ontario & $\begin{array}{l}39187 \\
(2282)\end{array}$ & $\begin{array}{l}26842 \\
(1623)\end{array}$ & $\begin{array}{l}25005 \\
(1291)\end{array}$ & $\begin{array}{l}19600 \\
(1066)\end{array}$ & $\begin{array}{l}20226 \\
(1251)\end{array}$ & $\begin{array}{r}18039 \\
(548)\end{array}$ \\
\hline Manitoba & $\begin{array}{r}32750 \\
(1950)\end{array}$ & $\begin{array}{l}23373 \\
(1462)\end{array}$ & $\begin{array}{l}22553 \\
(1166)\end{array}$ & $\begin{array}{r}17383 \\
(947)\end{array}$ & $\begin{array}{l}20101 \\
(1265)\end{array}$ & $\begin{array}{r}17245 \\
(1131)\end{array}$ \\
\hline Saskatchewan & $\begin{array}{l}28322 \\
(1714)\end{array}$ & $\begin{array}{l}23248 \\
(1437)\end{array}$ & $\begin{array}{l}22793 \\
(1188)\end{array}$ & $\begin{array}{r}15783 \\
(850)\end{array}$ & $\begin{array}{l}23305 \\
(1471)\end{array}$ & $\begin{array}{l}18441 \\
(1208)\end{array}$ \\
\hline Alberta & $\begin{array}{l}36200 \\
(2123)\end{array}$ & $\begin{array}{l}23558 \\
(1448)\end{array}$ & $\begin{array}{l}31299 \\
(1645)\end{array}$ & $\begin{array}{l}21736 \\
(1191)\end{array}$ & $\begin{array}{l}29090 \\
(1789)\end{array}$ & $\begin{array}{l}23714 \\
(1532)\end{array}$ \\
\hline British Columbia & $\begin{array}{l}30826 \\
(1795)\end{array}$ & $\begin{array}{l}20017 \\
(1244)\end{array}$ & $\begin{array}{l}21232 \\
(1114)\end{array}$ & $\begin{array}{r}15903 \\
(885)\end{array}$ & $\begin{array}{l}16869 \\
(1057)\end{array}$ & $\begin{array}{r}13995 \\
(924)\end{array}$ \\
\hline
\end{tabular}

Note:

The number of indiduals in each subsample is in parentheses. 
Table 7: Random Effect Probit Estimates for Each of the three Groups of Men for all Provinces, 1972-1992.

\begin{tabular}{|c|c|c|c|c|c|c|}
\hline & \multicolumn{4}{|c|}{ Men born before 1946 Men born in $1946-55$} & \multicolumn{2}{|c|}{ Men born after 1955} \\
\hline & $\begin{array}{l}\text { Main } \\
\text { Effect } \\
\text { (1a) }\end{array}$ & $\begin{array}{c}\text { Interact. } \\
\text { with } \\
\text { Learning } \\
\text { (1b) }\end{array}$ & $\begin{array}{l}\text { Main } \\
\text { Effect } \\
(2 a)\end{array}$ & $\begin{array}{c}\text { Interact. } \\
\text { with } \\
\text { Learning } \\
\text { (2b) }\end{array}$ & $\begin{array}{l}\text { Main } \\
\text { Effect } \\
\text { (3a) }\end{array}$ & $\begin{array}{c}\text { Interact. } \\
\text { with } \\
\text { Learning } \\
\text { (3b) }\end{array}$ \\
\hline Intercept & $\begin{array}{l}-1.168 \\
(0.100)\end{array}$ & $\begin{array}{c}0.381 \\
(0.138)\end{array}$ & $\begin{array}{l}-1.441 \\
(0.120)\end{array}$ & $\begin{array}{c}0.368 \\
(0.148)\end{array}$ & $\begin{array}{c}-1.285 \\
(0.13625)\end{array}$ & $\begin{array}{c}0.068 \\
(0.229)\end{array}$ \\
\hline First Lag & $\begin{array}{c}0.549 \\
(0.012)\end{array}$ & --- & $\begin{array}{c}0.420 \\
(0.012)\end{array}$ & --- & $\begin{array}{c}0.421 \\
(0.012)\end{array}$ & --- \\
\hline Second Lag & $\begin{array}{c}0.508 \\
(0.012)\end{array}$ & --- & $\begin{array}{c}0.422 \\
(0.012)\end{array}$ & --- & $\begin{array}{c}0.411 \\
(0.011)\end{array}$ & --- \\
\hline Third Lag & $\begin{array}{c}0.316 \\
(0.012)\end{array}$ & --- & $\begin{array}{c}0.250 \\
(0.012)\end{array}$ & --- & $\begin{array}{c}0.239 \\
(0.011)\end{array}$ & --- \\
\hline Fourth Lag & $\begin{array}{c}0.223 \\
(0.013)\end{array}$ & --- & $\begin{array}{c}0.208 \\
(0.012)\end{array}$ & --- & $\begin{array}{c}0.145 \\
(0.011)\end{array}$ & --- \\
\hline Age & $\begin{array}{l}-0.079 \\
(0.020)\end{array}$ & --- & $\begin{array}{l}-0.319 \\
(0.018)\end{array}$ & --- & $\begin{array}{l}-0.491 \\
(0.027)\end{array}$ & --- \\
\hline Age squared & $\begin{array}{c}0.018 \\
(0.005)\end{array}$ & --- & $\begin{array}{c}0.133 \\
(0.012)\end{array}$ & --- & $\begin{array}{l}-0.381 \\
(0.020)\end{array}$ & --- \\
\hline Subsidy Rate & $\begin{array}{c}0.097 \\
(0.029)\end{array}$ & $\begin{array}{c}0.069 \\
(0.039)\end{array}$ & $\begin{array}{c}0.122 \\
(0.033)\end{array}$ & $\begin{array}{l}-0.011 \\
(0.042)\end{array}$ & $\begin{array}{c}0.120 \\
(0.033)\end{array}$ & $\begin{array}{c}0.019 \\
(0.044)\end{array}$ \\
\hline Province Dummi & & & & & & \\
\hline Nova Scotia & $\begin{array}{l}-0.399 \\
(0.040)\end{array}$ & $\begin{array}{c}0.116 \\
(0.045)\end{array}$ & $\begin{array}{c}0.023 \\
(0.039)\end{array}$ & $\begin{array}{l}-0.189 \\
(0.048)\end{array}$ & $\begin{array}{l}-0.213 \\
(0.040)\end{array}$ & $\begin{array}{c}0.202 \\
(0.041)\end{array}$ \\
\hline New Brunswick & $\begin{array}{l}-0.307 \\
(0.037)\end{array}$ & $\begin{array}{c}0.135 \\
(0.039)\end{array}$ & $\begin{array}{c}0.074 \\
(0.032)\end{array}$ & $\begin{array}{l}-0.133 \\
(0.041)\end{array}$ & $\begin{array}{l}-0.280 \\
(0.036)\end{array}$ & $\begin{array}{c}0.038 \\
(0.046)\end{array}$ \\
\hline Quebec & $\begin{array}{l}-0.293 \\
(0.039)\end{array}$ & $\begin{array}{l}-0.067 \\
(0.044)\end{array}$ & $\begin{array}{c}0.059 \\
(0.036)\end{array}$ & $\begin{array}{l}-0.302 \\
(0.046)\end{array}$ & $\begin{array}{l}-0.299 \\
(0.039)\end{array}$ & $\begin{array}{c}0.170 \\
(0.060)\end{array}$ \\
\hline Ontario & $\begin{array}{l}-0.423 \\
(0.050)\end{array}$ & $\begin{array}{l}-0.034 \\
(0.059)\end{array}$ & $\begin{array}{l}-0.004 \\
(0.052)\end{array}$ & $\begin{array}{l}-0.351 \\
(0.063)\end{array}$ & $\begin{array}{l}-0.548 \\
(0.050)\end{array}$ & $\begin{array}{c}0.267 \\
(0.059)\end{array}$ \\
\hline Manitoba & $\begin{array}{l}-0.446 \\
(0.050)\end{array}$ & $\begin{array}{c}0.029 \\
(0.059)\end{array}$ & $\begin{array}{l}-0.001 \\
(0.051)\end{array}$ & $\begin{array}{l}-0.354 \\
(0.062)\end{array}$ & $\begin{array}{l}-0.588 \\
(0.050)\end{array}$ & $\begin{array}{c}0.297 \\
(0.061)\end{array}$ \\
\hline
\end{tabular}


Table 7 (continuation)

\begin{tabular}{|c|c|c|c|c|c|c|}
\hline & (1a) & (1b) & (2a) & (2b) & (3a) & (3b) \\
\hline Saskatchewan & $\begin{array}{l}-0.519 \\
(0.053)\end{array}$ & $\begin{array}{c}0.114 \\
(0.063)\end{array}$ & $\begin{array}{l}-0.235 \\
(0.053)\end{array}$ & $\begin{array}{l}-0.184 \\
(0.066)\end{array}$ & $\begin{array}{l}-0.613 \\
(0.052)\end{array}$ & $\begin{array}{c}0.571 \\
(0.057)\end{array}$ \\
\hline Alberta & $\begin{array}{l}-0.699 \\
(0.051)\end{array}$ & $\begin{array}{c}0.149 \\
(0.060)\end{array}$ & $\begin{array}{l}-0.463 \\
(0.052)\end{array}$ & $\begin{array}{c}0.019 \\
(0.064)\end{array}$ & $\begin{array}{l}-0.986 \\
(0.049)\end{array}$ & $\begin{array}{r}0.303 \\
(0.050)\end{array}$ \\
\hline $\begin{array}{l}\text { British } \\
\text { Columbia }\end{array}$ & $\begin{array}{l}-0.448 \\
(0.044)\end{array}$ & $\begin{array}{c}0.048 \\
(0.049)\end{array}$ & $\begin{array}{l}-0.197 \\
(0.043)\end{array}$ & $\begin{array}{l}-0.120 \\
(0.053)\end{array}$ & $\begin{array}{l}-0.605 \\
(0.043)\end{array}$ & $\begin{array}{r}0.288 \\
(0.050)\end{array}$ \\
\hline \multicolumn{7}{|l|}{ Year Dummies } \\
\hline Year 1973 & $\begin{array}{r}-0.352 \\
0.026\end{array}$ & -- & $\begin{array}{r}-0.187 \\
0.025\end{array}$ & --- & $\begin{array}{r}-0.060 \\
0.085\end{array}$ & --- \\
\hline Year 1974 & $\begin{array}{r}-0.578 \\
0.030\end{array}$ & $\begin{array}{l}0.022 \\
0.055\end{array}$ & $\begin{array}{r}-0.312 \\
0.028\end{array}$ & $\begin{array}{l}0.064 \\
0.051\end{array}$ & $\begin{array}{l}0.087 \\
0.079\end{array}$ & $\begin{array}{r}-0.148 \\
0.199\end{array}$ \\
\hline Year 1975 & $\begin{array}{r}-0.401 \\
0.029\end{array}$ & $\begin{array}{r}-0.255 \\
0.053\end{array}$ & $\begin{array}{r}-0.208 \\
0.029\end{array}$ & $\begin{array}{r}-0.058 \\
0.051\end{array}$ & $\begin{array}{l}0.301 \\
0.077\end{array}$ & $\begin{array}{r}-0.060 \\
0.189\end{array}$ \\
\hline Year 1976 & $\begin{array}{r}-0.569 \\
0.032\end{array}$ & $\begin{array}{r}-0.150 \\
0.054\end{array}$ & $\begin{array}{r}-0.314 \\
0.032\end{array}$ & $\begin{array}{l}0.028 \\
0.052\end{array}$ & $\begin{array}{l}0.233 \\
0.077\end{array}$ & $\begin{array}{r}-0.171 \\
0.188\end{array}$ \\
\hline Year 1977 & $\begin{array}{r}-0.466 \\
0.031\end{array}$ & $\begin{array}{r}-0.242 \\
0.053\end{array}$ & $\begin{array}{r}-0.251 \\
0.034\end{array}$ & $\begin{array}{r}-0.011 \\
0.053\end{array}$ & $\begin{array}{l}0.338 \\
0.077\end{array}$ & $\begin{array}{r}-0.363 \\
0.186\end{array}$ \\
\hline Year 1978 & $\begin{array}{r}-0.458 \\
0.032\end{array}$ & $\begin{array}{r}-0.267 \\
0.054\end{array}$ & $\begin{array}{r}-0.240 \\
0.036\end{array}$ & $\begin{array}{r}-0.013 \\
0.054\end{array}$ & $\begin{array}{l}0.393 \\
0.077\end{array}$ & $\begin{array}{r}-0.462 \\
0.185\end{array}$ \\
\hline Year 1979 & $\begin{array}{r}-0.534 \\
0.041\end{array}$ & $\begin{array}{r}-0.084 \\
0.063\end{array}$ & $\begin{array}{r}-0.332 \\
0.049\end{array}$ & $\begin{array}{l}0.057 \\
0.065\end{array}$ & $\begin{array}{l}0.256 \\
0.081\end{array}$ & $\begin{array}{r}-0.351 \\
0.187\end{array}$ \\
\hline Year 1980 & $\begin{array}{r}-0.406 \\
0.040\end{array}$ & $\begin{array}{r}-0.133 \\
0.062\end{array}$ & $\begin{array}{r}-0.327 \\
0.050\end{array}$ & $\begin{array}{l}0.170 \\
0.066\end{array}$ & $\begin{array}{l}0.277 \\
0.081\end{array}$ & $\begin{array}{r}-0.345 \\
0.187\end{array}$ \\
\hline Year 1981 & $\begin{array}{r}-0.302 \\
0.042\end{array}$ & $\begin{array}{r}-0.256 \\
0.063\end{array}$ & $\begin{array}{r}-0.279 \\
0.052\end{array}$ & $\begin{array}{l}0.183 \\
0.068\end{array}$ & $\begin{array}{l}0.411 \\
0.081\end{array}$ & $\begin{array}{r}-0.427 \\
0.187\end{array}$ \\
\hline Year 1982 & $\begin{array}{l}0.036 \\
0.035\end{array}$ & $\begin{array}{r}-0.366 \\
0.055\end{array}$ & $\begin{array}{l}0.022 \\
0.044\end{array}$ & $\begin{array}{l}0.177 \\
0.057\end{array}$ & $\begin{array}{l}0.706 \\
0.079\end{array}$ & $\begin{array}{r}-0.564 \\
0.184\end{array}$ \\
\hline Year 1983 & $\begin{array}{r}-0.126 \\
0.036\end{array}$ & $\begin{array}{r}-0.373 \\
0.055\end{array}$ & $\begin{array}{r}-0.236 \\
0.047\end{array}$ & $\begin{array}{l}0.268 \\
0.059\end{array}$ & $\begin{array}{l}0.444 \\
0.079\end{array}$ & $\begin{array}{r}-0.429 \\
0.184\end{array}$ \\
\hline Year 1984 & $\begin{array}{r}-0.046 \\
0.037\end{array}$ & $\begin{array}{r}-0.475 \\
0.055\end{array}$ & $\begin{array}{r}-0.335 \\
0.052\end{array}$ & $\begin{array}{l}0.362 \\
0.062\end{array}$ & $\begin{array}{l}0.340 \\
0.081\end{array}$ & $\begin{array}{r}-0.356 \\
0.184\end{array}$ \\
\hline
\end{tabular}


Table 7 (continuation)

\begin{tabular}{|c|c|c|c|c|c|c|}
\hline & (1a) & (1b) & (2a) & (2b) & (3a) & (3b) \\
\hline Year 1985 & $\begin{array}{l}-0.241 \\
(0.042)\end{array}$ & $\begin{array}{l}-0.322 \\
(0.059)\end{array}$ & $\begin{array}{l}-0.414 \\
(0.056)\end{array}$ & $\begin{array}{c}0.347 \\
(0.065)\end{array}$ & $\begin{array}{c}0.322 \\
(0.082)\end{array}$ & $\begin{array}{l}-0.433 \\
(0.185)\end{array}$ \\
\hline Year 1986 & $\begin{array}{l}-0.341 \\
(0.047)\end{array}$ & $\begin{array}{l}-0.280 \\
(0.064)\end{array}$ & $\begin{array}{l}-0.384 \\
(0.057)\end{array}$ & $\begin{array}{c}0.426 \\
(0.066)\end{array}$ & $\begin{array}{c}0.265 \\
(0.085)\end{array}$ & $\begin{array}{l}-0.343 \\
(0.186)\end{array}$ \\
\hline Year 1987 & $\begin{array}{l}-0.330 \\
(0.049)\end{array}$ & $\begin{array}{l}-0.288 \\
(0.065)\end{array}$ & $\begin{array}{l}-0.518 \\
(0.063)\end{array}$ & $\begin{array}{c}0.438 \\
(0.071)\end{array}$ & $\begin{array}{c}0.117 \\
(0.088)\end{array}$ & $\begin{array}{l}-0.293 \\
(0.187)\end{array}$ \\
\hline Year 1988 & $\begin{array}{l}-0.340 \\
(0.052)\end{array}$ & $\begin{array}{l}-0.265 \\
(0.069)\end{array}$ & $\begin{array}{l}-0.630 \\
(0.072)\end{array}$ & $\begin{array}{c}0.570 \\
(0.079)\end{array}$ & $\begin{array}{c}0.068 \\
(0.090)\end{array}$ & $\begin{array}{l}-0.200 \\
(0.188)\end{array}$ \\
\hline Year 1989 & $\begin{array}{l}-0.255 \\
(0.053)\end{array}$ & $\begin{array}{l}-0.304 \\
(0.069)\end{array}$ & $\begin{array}{l}-0.422 \\
(0.066)\end{array}$ & $\begin{array}{c}0.426 \\
(0.074)\end{array}$ & $\begin{array}{c}0.002 \\
(0.094)\end{array}$ & $\begin{array}{l}-0.071 \\
(0.190)\end{array}$ \\
\hline Year 1990 & $\begin{array}{l}-0.154 \\
(0.053)\end{array}$ & $\begin{array}{l}-0.344 \\
(0.069)\end{array}$ & $\begin{array}{l}-0.320 \\
(0.068)\end{array}$ & $\begin{array}{c}0.359 \\
(0.074)\end{array}$ & $\begin{array}{c}0.150 \\
(0.093)\end{array}$ & $\begin{array}{l}-0.141 \\
(0.190)\end{array}$ \\
\hline Year 1991 & $\begin{array}{l}-0.082 \\
(0.055)\end{array}$ & $\begin{array}{l}-0.346 \\
(0.071)\end{array}$ & $\begin{array}{l}-0.451 \\
(0.074)\end{array}$ & $\begin{array}{c}0.579 \\
(0.079)\end{array}$ & $\begin{array}{c}0.270 \\
(0.094)\end{array}$ & $\begin{array}{l}-0.191 \\
(0.190)\end{array}$ \\
\hline Year 1992 & $\begin{array}{c}0.237 \\
(0.057)\end{array}$ & $\begin{array}{l}-0.459 \\
(0.071)\end{array}$ & $\begin{array}{l}-0.221 \\
(0.073)\end{array}$ & $\begin{array}{c}0.438 \\
(0.076)\end{array}$ & $\begin{array}{c}0.358 \\
(0.098)\end{array}$ & $\begin{array}{l}-0.077 \\
(0.192)\end{array}$ \\
\hline \multicolumn{7}{|c|}{ Heterogeneity parameters } \\
\hline $\begin{array}{l}\text { Variance of } \\
\text { Intercept }\end{array}$ & $\begin{array}{c}0.4436 \\
(0.0311)\end{array}$ & & $\begin{array}{c}0.0456 \\
(0.0099)\end{array}$ & & $\begin{array}{c}0.0512 \\
(0.0073)\end{array}$ & \\
\hline $\begin{array}{l}\text { Variance of } \\
\text { Learning Coeff. }\end{array}$ & $\begin{array}{c}0.0626 \\
(0.0133)\end{array}$ & & $\begin{array}{c}0.2024 \\
(0.0110)\end{array}$ & & $\begin{array}{c}0.0228 \\
(0.0061)\end{array}$ & \\
\hline Covariance & $\begin{array}{l}-0.1666 \\
(0.0169)\end{array}$ & & $\begin{array}{l}-0.0069 \\
(0.0050)\end{array}$ & & $\begin{array}{c}0.0321 \\
(0.0047)\end{array}$ & \\
\hline$\frac{\text { Observations: }}{\text { (persons) }}$ & $\begin{array}{l}273600 \\
(16015)\end{array}$ & & $\begin{array}{l}201695 \\
(10420)\end{array}$ & & $\begin{array}{l}169681 \\
(10547)\end{array}$ & \\
\hline Log-likelihood: & -71054.8 & & -68441.82 & & -73401.1 & \\
\hline
\end{tabular}

Note: $\quad$ The subsidy rate is the UI replacement rate multiplied by the maximum number of weeks of eligibity and divided by the minimum number of weeks to qualify. Unobserved heterogeneity in the intercept and the learning coefficient is modelled as a bivariate standard normal distribution. The model is estimated by simulated maximum likelihood (20 draws). Nine industry dummies are also included in all models. 
Table 8: Random Effect Probit Estimates for Each of the three Groups of Women for all Provinces, 1972-1992.

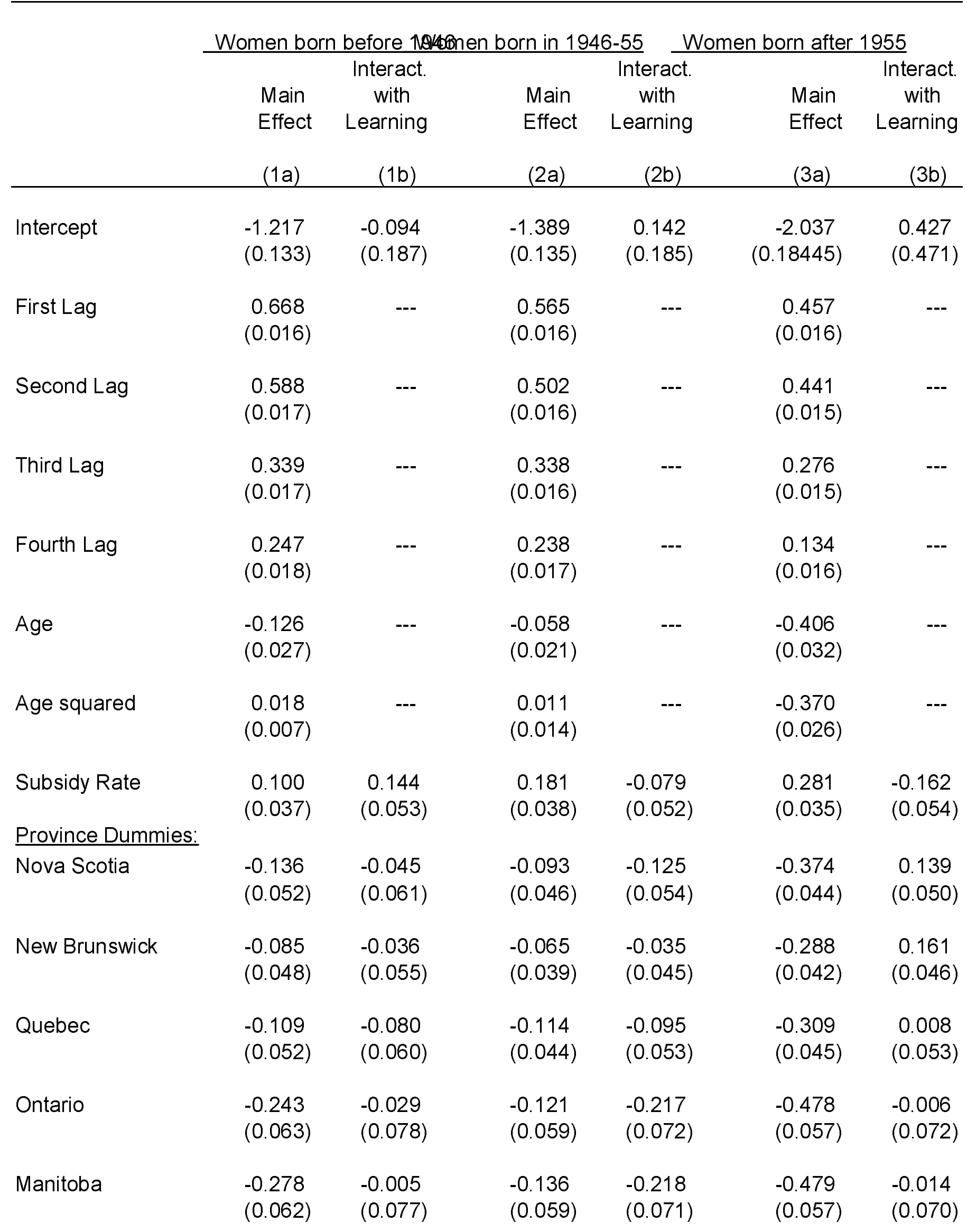


Table 8 (continuation)

\begin{tabular}{|c|c|c|c|c|c|c|}
\hline & (1a) & (1b) & (2a) & (2b) & (3a) & (3b) \\
\hline Saskatchewan & $\begin{array}{l}-0.451 \\
(0.066)\end{array}$ & $\begin{array}{c}0.108 \\
(0.081)\end{array}$ & $\begin{array}{l}-0.170 \\
(0.062)\end{array}$ & $\begin{array}{l}-0.283 \\
(0.076)\end{array}$ & $\begin{array}{l}-0.523 \\
(0.059)\end{array}$ & $\begin{array}{r}0.019 \\
(0.073)\end{array}$ \\
\hline Alberta & $\begin{array}{l}-0.478 \\
(0.063)\end{array}$ & $\begin{array}{c}0.066 \\
(0.079)\end{array}$ & $\begin{array}{l}-0.455 \\
(0.059)\end{array}$ & $\begin{array}{l}-0.022 \\
(0.074)\end{array}$ & $\begin{array}{l}-0.814 \\
(0.056)\end{array}$ & $\begin{array}{c}0.291 \\
(0.069)\end{array}$ \\
\hline $\begin{array}{l}\text { British } \\
\text { Columbia }\end{array}$ & $\begin{array}{l}-0.311 \\
(0.056)\end{array}$ & $\begin{array}{c}0.052 \\
(0.066)\end{array}$ & $\begin{array}{l}-0.313 \\
(0.050)\end{array}$ & $\begin{array}{c}0.006 \\
(0.060)\end{array}$ & $\begin{array}{l}-0.472 \\
(0.049)\end{array}$ & $\begin{array}{c}0.054 \\
(0.058)\end{array}$ \\
\hline \multicolumn{7}{|l|}{ Year Dummies } \\
\hline Year 1973 & $\begin{array}{r}-0.166 \\
0.034\end{array}$ & --- & $\begin{array}{r}-0.122 \\
0.034\end{array}$ & --- & $\begin{array}{l}0.241 \\
0.150\end{array}$ & --- \\
\hline Year 1974 & $\begin{array}{r}-0.303 \\
0.037\end{array}$ & $\begin{array}{r}-0.133 \\
0.080\end{array}$ & $\begin{array}{r}-0.199 \\
0.036\end{array}$ & $\begin{array}{r}-0.014 \\
0.083\end{array}$ & $\begin{array}{l}0.236 \\
0.142\end{array}$ & $\begin{array}{l}0.351 \\
0.470\end{array}$ \\
\hline Year 1975 & $\begin{array}{r}-0.428 \\
0.039\end{array}$ & $\begin{array}{r}-0.117 \\
0.077\end{array}$ & $\begin{array}{r}-0.180 \\
0.037\end{array}$ & $\begin{array}{l}0.029 \\
0.082\end{array}$ & $\begin{array}{l}0.323 \\
0.139\end{array}$ & $\begin{array}{r}-0.071 \\
0.463\end{array}$ \\
\hline Year 1976 & $\begin{array}{r}-0.404 \\
0.039\end{array}$ & $\begin{array}{r}-0.184 \\
0.077\end{array}$ & $\begin{array}{r}-0.222 \\
0.039\end{array}$ & $\begin{array}{l}0.015 \\
0.080\end{array}$ & $\begin{array}{l}0.370 \\
0.138\end{array}$ & $\begin{array}{r}-0.142 \\
0.441\end{array}$ \\
\hline Year 1977 & $\begin{array}{r}-0.363 \\
0.040\end{array}$ & $\begin{array}{r}-0.205 \\
0.076\end{array}$ & $\begin{array}{r}-0.298 \\
0.042\end{array}$ & $\begin{array}{l}0.118 \\
0.081\end{array}$ & $\begin{array}{l}0.452 \\
0.138\end{array}$ & $\begin{array}{r}-0.143 \\
0.444\end{array}$ \\
\hline Year 1978 & $\begin{array}{r}-0.358 \\
0.041\end{array}$ & $\begin{array}{r}-0.319 \\
0.076\end{array}$ & $\begin{array}{r}-0.250 \\
0.043\end{array}$ & $\begin{array}{l}0.040 \\
0.080\end{array}$ & $\begin{array}{l}0.536 \\
0.137\end{array}$ & $\begin{array}{r}-0.221 \\
0.442\end{array}$ \\
\hline Year 1979 & $\begin{array}{r}-0.381 \\
0.051\end{array}$ & $\begin{array}{r}-0.068 \\
0.087\end{array}$ & $\begin{array}{r}-0.217 \\
0.054\end{array}$ & $\begin{array}{l}0.004 \\
0.091\end{array}$ & $\begin{array}{l}0.600 \\
0.140\end{array}$ & $\begin{array}{r}-0.382 \\
0.445\end{array}$ \\
\hline Year 1980 & $\begin{array}{r}-0.293 \\
0.050\end{array}$ & $\begin{array}{r}-0.027 \\
0.085\end{array}$ & $\begin{array}{r}-0.201 \\
0.055\end{array}$ & $\begin{array}{l}0.056 \\
0.090\end{array}$ & $\begin{array}{l}0.547 \\
0.140\end{array}$ & $\begin{array}{r}-0.324 \\
0.444\end{array}$ \\
\hline Year 1981 & $\begin{array}{r}-0.232 \\
0.053\end{array}$ & $\begin{array}{r}-0.070 \\
0.087\end{array}$ & $\begin{array}{r}-0.235 \\
0.059\end{array}$ & $\begin{array}{l}0.159 \\
0.092\end{array}$ & $\begin{array}{l}0.697 \\
0.141\end{array}$ & $\begin{array}{r}-0.397 \\
0.444\end{array}$ \\
\hline Year 1982 & $\begin{array}{r}-0.094 \\
0.046\end{array}$ & $\begin{array}{r}-0.126 \\
0.078\end{array}$ & $\begin{array}{r}-0.154 \\
0.053\end{array}$ & $\begin{array}{l}0.225 \\
0.084\end{array}$ & $\begin{array}{l}0.820 \\
0.139\end{array}$ & $\begin{array}{r}-0.428 \\
0.443\end{array}$ \\
\hline Year 1983 & $\begin{array}{r}-0.133 \\
0.046\end{array}$ & $\begin{array}{r}-0.178 \\
0.076\end{array}$ & $\begin{array}{r}-0.240 \\
0.053\end{array}$ & $\begin{array}{l}0.277 \\
0.082\end{array}$ & $\begin{array}{l}0.663 \\
0.139\end{array}$ & $\begin{array}{r}-0.331 \\
0.443\end{array}$ \\
\hline Year 1984 & $\begin{array}{r}-0.061 \\
0.049\end{array}$ & $\begin{array}{r}-0.217 \\
0.078\end{array}$ & $\begin{array}{r}-0.254 \\
0.056\end{array}$ & $\begin{array}{l}0.298 \\
0.084\end{array}$ & $\begin{array}{l}0.709 \\
0.140\end{array}$ & $\begin{array}{r}-0.301 \\
0.443\end{array}$ \\
\hline
\end{tabular}


Table 8 (continuation)

\begin{tabular}{|c|c|c|c|c|c|c|}
\hline & (1a) & $(1 \mathrm{~b})$ & (2a) & (2b) & (3a) & (3b) \\
\hline Year 1985 & $\begin{array}{l}-0.170 \\
(0.053)\end{array}$ & $\begin{array}{l}-0.141 \\
(0.080)\end{array}$ & $\begin{array}{l}-0.378 \\
(0.060)\end{array}$ & $\begin{array}{c}0.361 \\
(0.086)\end{array}$ & $\begin{array}{c}0.616 \\
(0.141)\end{array}$ & $\begin{array}{l}-0.263 \\
(0.443)\end{array}$ \\
\hline Year 1986 & $\begin{array}{l}-0.132 \\
(0.055)\end{array}$ & $\begin{array}{l}-0.117 \\
(0.083)\end{array}$ & $\begin{array}{l}-0.324 \\
(0.063)\end{array}$ & $\begin{array}{c}0.302 \\
(0.088)\end{array}$ & $\begin{array}{c}0.637 \\
(0.143)\end{array}$ & $\begin{array}{l}-0.264 \\
(0.443)\end{array}$ \\
\hline Year 1987 & $\begin{array}{l}-0.167 \\
(0.058)\end{array}$ & $\begin{array}{l}-0.155 \\
(0.086)\end{array}$ & $\begin{array}{l}-0.426 \\
(0.066)\end{array}$ & $\begin{array}{c}0.434 \\
(0.089)\end{array}$ & $\begin{array}{c}0.604 \\
(0.144)\end{array}$ & $\begin{array}{l}-0.227 \\
(0.443)\end{array}$ \\
\hline Year 1988 & $\begin{array}{l}-0.122 \\
(0.062)\end{array}$ & $\begin{array}{l}-0.119 \\
(0.089)\end{array}$ & $\begin{array}{l}-0.344 \\
(0.069)\end{array}$ & $\begin{array}{c}0.344 \\
(0.093)\end{array}$ & $\begin{array}{c}0.599 \\
(0.146)\end{array}$ & $\begin{array}{l}-0.195 \\
(0.444)\end{array}$ \\
\hline Year 1989 & $\begin{array}{l}-0.121 \\
(0.064)\end{array}$ & $\begin{array}{l}-0.137 \\
(0.091)\end{array}$ & $\begin{array}{l}-0.334 \\
(0.070)\end{array}$ & $\begin{array}{c}0.356 \\
(0.094)\end{array}$ & $\begin{array}{c}0.630 \\
(0.146)\end{array}$ & $\begin{array}{l}-0.208 \\
(0.445)\end{array}$ \\
\hline Year 1990 & $\begin{array}{l}-0.042 \\
(0.066)\end{array}$ & $\begin{array}{l}-0.144 \\
(0.094)\end{array}$ & $\begin{array}{l}-0.409 \\
(0.075)\end{array}$ & $\begin{array}{c}0.459 \\
(0.097)\end{array}$ & $\begin{array}{c}0.711 \\
(0.147)\end{array}$ & $\begin{array}{l}-0.248 \\
(0.445)\end{array}$ \\
\hline Year 1991 & $\begin{array}{c}0.129 \\
(0.067)\end{array}$ & $\begin{array}{l}-0.304 \\
(0.094)\end{array}$ & $\begin{array}{l}-0.389 \\
(0.078)\end{array}$ & $\begin{array}{c}0.453 \\
(0.098)\end{array}$ & $\begin{array}{c}0.609 \\
(0.150)\end{array}$ & $\begin{array}{l}-0.099 \\
(0.446)\end{array}$ \\
\hline Year 1992 & $\begin{array}{c}0.306 \\
(0.072)\end{array}$ & $\begin{array}{l}-0.226 \\
(0.096)\end{array}$ & $\begin{array}{l}-0.195 \\
(0.080)\end{array}$ & $\begin{array}{c}0.460 \\
(0.098)\end{array}$ & $\begin{array}{c}0.954 \\
(0.151)\end{array}$ & $\begin{array}{l}-0.079 \\
(0.446)\end{array}$ \\
\hline \multicolumn{7}{|c|}{ Heterogeneity parameters } \\
\hline $\begin{array}{l}\text { Variance of } \\
\text { Intercept }\end{array}$ & $\begin{array}{c}0.4206 \\
(0.0369)\end{array}$ & & $\begin{array}{c}0.0916 \\
(0.0145)\end{array}$ & & $\begin{array}{c}0.0943 \\
(0.0139)\end{array}$ & \\
\hline $\begin{array}{l}\text { Variance of } \\
\text { Learning Coeff. }\end{array}$ & $\begin{array}{c}0.1450 \\
(0.0246)\end{array}$ & & $\begin{array}{c}0.0021 \\
(0.0020)\end{array}$ & & $\begin{array}{c}0.0011 \\
(0.0015)\end{array}$ & \\
\hline Covariance & $\begin{array}{l}-0.2309 \\
(0.0221)\end{array}$ & & $\begin{array}{c}0.0027 \\
(0.0073)\end{array}$ & & $\begin{array}{c}0.0050 \\
(0.0070)\end{array}$ & \\
\hline$\frac{\text { Observations: }}{\text { (persons) }}$ & $\begin{array}{l}173248 \\
(10774)\end{array}$ & & $\begin{array}{r}141428 \\
(7751)\end{array}$ & & $\begin{array}{r}138012 \\
(9058)\end{array}$ & \\
\hline Log-likelihood: & -42926.24 & & -41914.78 & & -46000.23 & \\
\hline
\end{tabular}

Note: $\quad$ The subsidy rate is the UI replacement rate multiplied by the maximum number of weeks of eligibity and divided by the minimum number of weeks to qualify. Unobserved heterogeneity in the intercept and the learning coefficient is modelled as a bivariate standard normal distribution. The model is estimated by simulated maximum likelihood (20 draws). Nine industry dummies are also included in all models. 
Figure 1

\section{Evolution of Subsidy Rate}

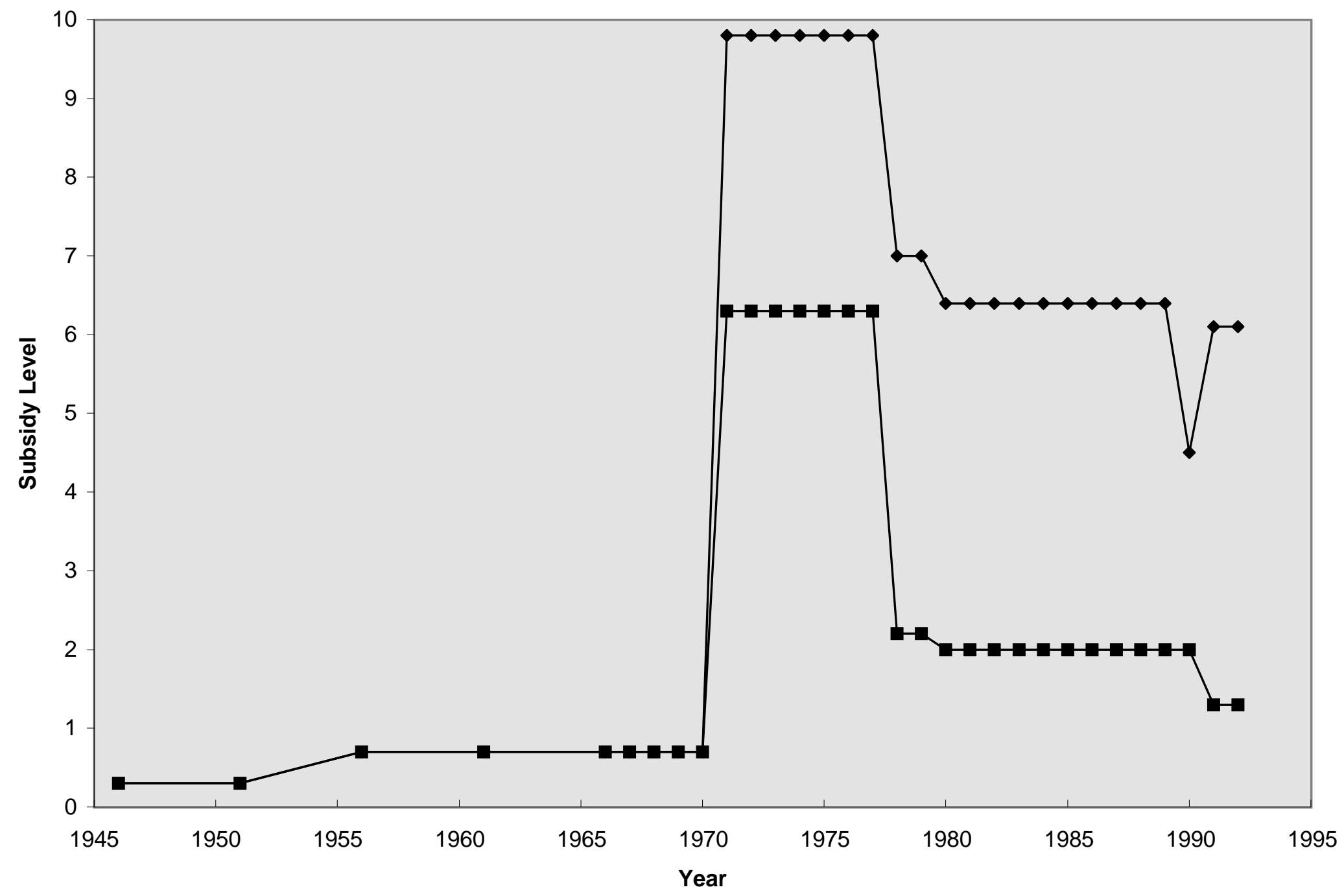




\section{Evolution of Unemployment Insurance Use}

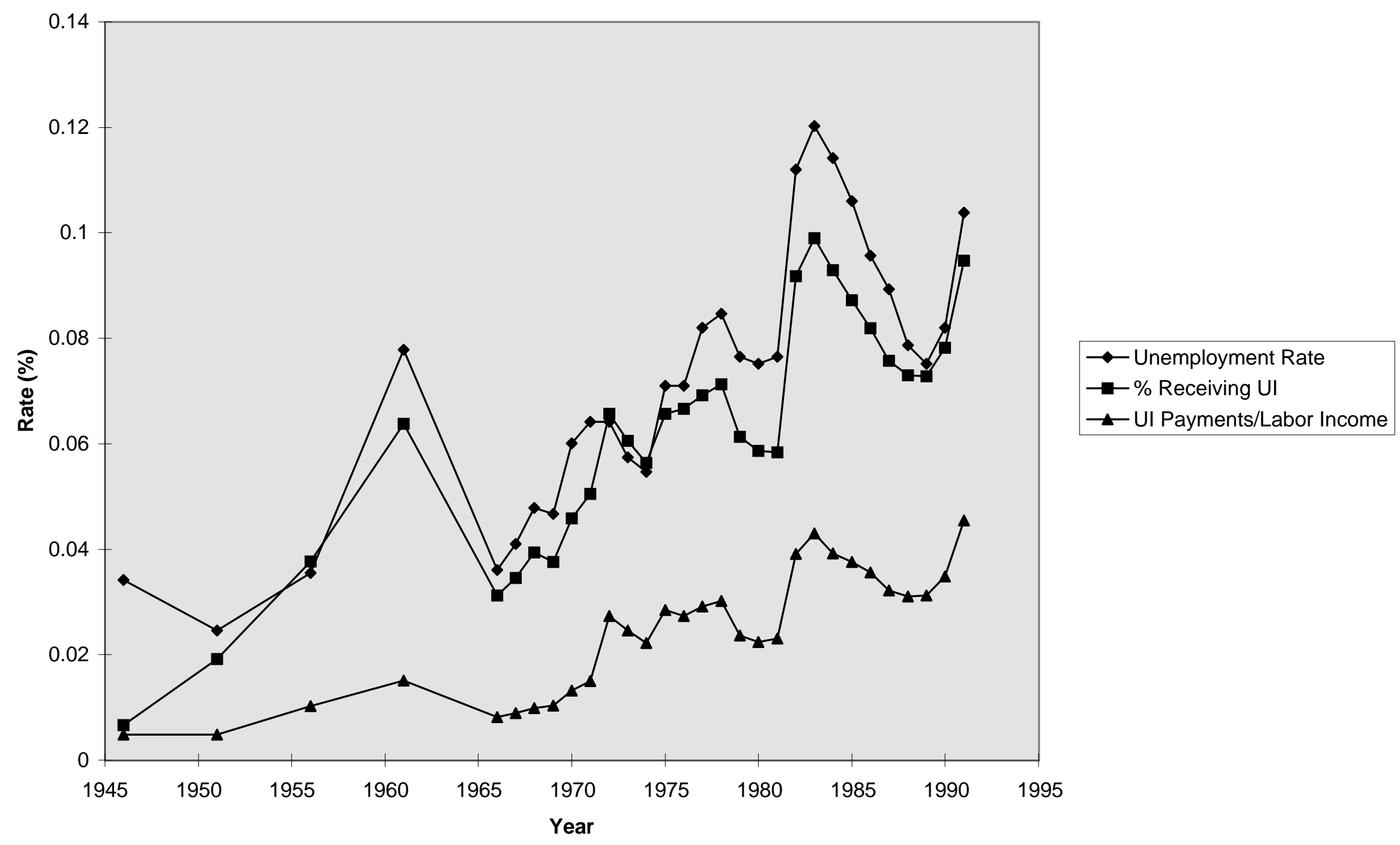

